\title{
Reconstruction of the depositional sedimentary environment of Oligocene deposits (Qom Formation) in the Qom Basin (northern Tethyan seaway), Iran
}

\author{
Amrollah Safari*, Hossein Ghanbarloo, Parisa Mansoury, \\ Mehran Mohammadian Esfahani
}

Department of Geology, University of Isfahan, 81746-73441 Isfahan, Iran

*corresponding author; e-mail: safari@sci.ui.ac.ir; a.safari901@gmail.com

\begin{abstract}
During the Rupelian-Chattian, the Qom Basin (northern seaway basin) was located between the Paratethys in the north and the southern Tethyan seaway in the south. The Oligocene deposits (Qom Formation) in the Qom Basin have been interpreted for a reconstruction of environmental conditions during deposition, as well as of the influence of local fault activities and global sea level changes expressed within the basin. We have also investigated connections between the Qom Basin and adjacent basins. Seven microfacies types have been distinguished in the former. These microfacies formed within three major depositional environments, i.e., restricted lagoon, open lagoon and open marine. Strata of the Qom Formation are suggested to have been formed in an open-shelf system. In addition, the deepening and shallowing patterns noted within the microfacies suggest the presence of three third-order sequences in the Bijegan area and two third-order depositional sequences and an incomplete depositional sequence in the Naragh area. Our analysis suggests that, during the Rupelian and Chattian stages, the depositional sequences of the Qom Basin were influenced primarily by local tectonics, while global sea level changes had a greater impact on the southern Tethyan seaway and Paratethys basins. The depositional basins of the Tethyan seaway (southern Tethyan seaway, Paratethys Basin and Qom Basin) were probably related during the Burdigalian to Langhian and early Serravallian.
\end{abstract}

Key words: Bijegan area, Naragh area, open shelf, central Iran, Tethyan Seaway

\section{Introduction}

The Tethyan Seaway was located between the supercontinents of Eurasia and Gondwana (Fig. 1), where researchers have argued that the Tethyan seaway basin was connected with the Paratethys during the Oligocene-Miocene (Harzhauser \& Piller, 2007; Reuter et al., 2009). However, these previous studies failed to constrain the timing of connection between these basins as either Oligocene or Miocene. Mahyad et al. (2019) have recently studied Miocene strata of the Qom Formation and suggest- ed this connection existed during the Burdigalian. The link between the northern and southern Tethyan seaway margins and Paratethys during the Oligocene remains unknown. Sequence-stratigraphical interpretations, based on microfacies analysis, have rarely been performed by researchers in the Qom Basin (Reuter et al., 2009; Mohammadi et al., 2011; Seddighi et al., 2011; Mahyad et al., 2018, 2019). Our study focuses on four main objectives: 1) to reconstruct the sedimentary environment and depositional sequences in the study areas based on microfacies distribution, 2) to correlate deposi- 


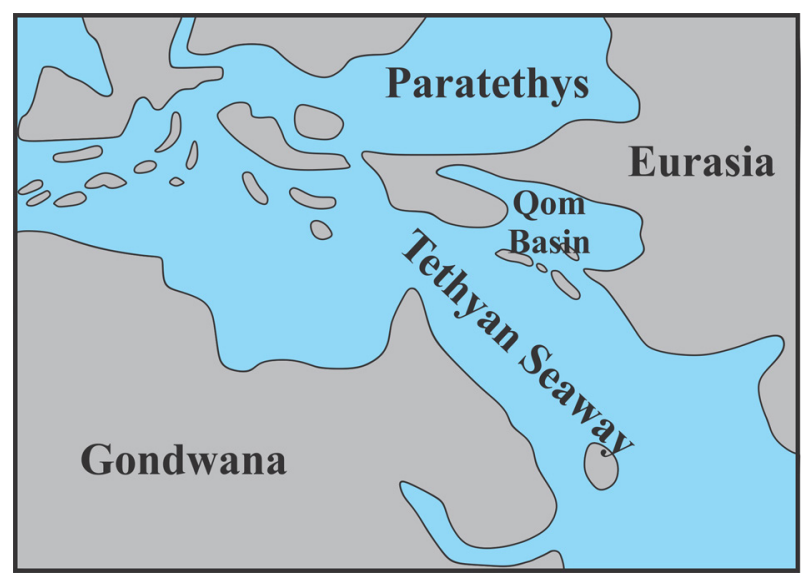

Fig. 1. Palaeogeographical map for the Oligocene Stage, showing the Tethyan Seaway, Paratethys and the Qom Basin (after Harzhauser \& Piller, 2007; Reuter et al., 2009)

tional sequences in the study areas with global sea level change and the fluctuation of sea level of the southern Tethyan seaway and Paratethys basins, 3) to consider the influence of local fault activities and global sea level change on the distribution of depositional sequences in the Qom Basin during the Rupelian, and 4) to study the connection between the northern and southern Tethyan seaway margins and Paratethys.

\section{Geological setting}

The Qom Basin was formed by marine transgression during the Late Oligocene and covered the western portions of central Iran (Aghanabati, 2006). Limestones and marls of the Qom Formation deposited here (Reuter et al., 2009) comprise a thick succession of marine marls, limestones, gypsum and siliciclastic rocks in the type section of the Qom Formation (Aghanabati, 2006; Reuter et al., 2009), which overlies both the Lower Red Formation as well as Eocene volcanic rocks (Aghanabati, 2006). The Qom Formation is conformably overlain by non-marine siltstones and evaporite-dominated beds of the Upper Red Formation (Stocklin \& Setudehnia, 1971). In the Naragh area, the Qom Formation reaches an overal thickness of $185 \mathrm{~m}$, and consists of thin-, medium- and thick-bedded limestone and can be divided into two lithostratigraphical units.

1. Unit A (Rupelian and Chattian stages): The first lithostratigraphical unit (thickness: $89.5 \mathrm{~m}$ ) comprises an alternation of thin-, medium- and thick-bedded cream and grey limestones.
2. Unit B (Chattian Stage): The second unit attains a thickness of $95.5 \mathrm{~m}$ and consists of thick-bedded grey limestones.

In the Bijegan area, the Qom Formation (thickness: $162 \mathrm{~m}$ ) consists of thin-, medium-, thick- and massively bedded limestone.

1. Unit A (Rupelian Stage): The first lithostratigraphical unit (thickness: $38 \mathrm{~m}$ ) comprises an alternation of thin-, medium- and thick-bedded cream limestones.

2. Unit B (Rupelian and Chattian stages): The second lithostratigraphical (thickness: $78 \mathrm{~m}$ ) is composed of medium-, thick- and massively bedded cream limestones.

3. Unit C (Chattian Stage): The third unit (thickness: $46 \mathrm{~m}$ ) consists of thick- and massively bedded cream limestones. The Qom Formation unconformably covers the Lower Red Formation in the study areas. Quaternary-aged alluvial strata overlie this formation in the study areas.

\section{Study area and methods}

Two stratigraphical sections from the Qom Formation have been investigated sedimentologically, taking a bed-by-bed approach. The study area is located in the Naragh area, about $26 \mathrm{~km}$ northeast of Delijan (northwest of Isfahan) (Fig. 2). The section in this area was measured in detail at the following co-ordinates, $34^{\circ} 04^{\prime} 26^{\prime \prime} \mathrm{N}$, 5053'36"E; from here over 130 thin sections have been studied. The Bijegan area (co-ordinates: $34^{\circ} 05^{\prime} 37^{\prime \prime} \mathrm{N}, 50^{\circ} 44^{\prime} 58^{\prime \prime} \mathrm{E}$ ) is located about $20 \mathrm{~km}$ northeast of Delijan (Fig. 2); from this area, a total of 120 thin sections have been examined. Our carbonate classification follows the schemes of Dunham (1962) and Embry \& Klovan (1972). Microfacies analyses of the thin sections were based on semi-quantitative component analysis and textural features (Flügel, 2010). The abundance of various coralline algae taxa in the section studied was used to interpret the microfacies. Taphonomic processes (i.e., fragmentation, abrasion, encrustation and bioerosion) in thin sections have been identified using the approach by Allison \& Bottjer (2011) and Silvestri et al. (2011) (Fig. 5). Qualitative estimates of pre-burial taphonomic features were performed based on the research of Silvestri et al. (2011) and Bover-Arnal et al. (2017). Beavington-Penney (2004) introduced a qualitative evaluation of test degradation among benthic foraminifera. This qualitative evaluation includes the following scores: (0) tests of large benthic foraminif- 

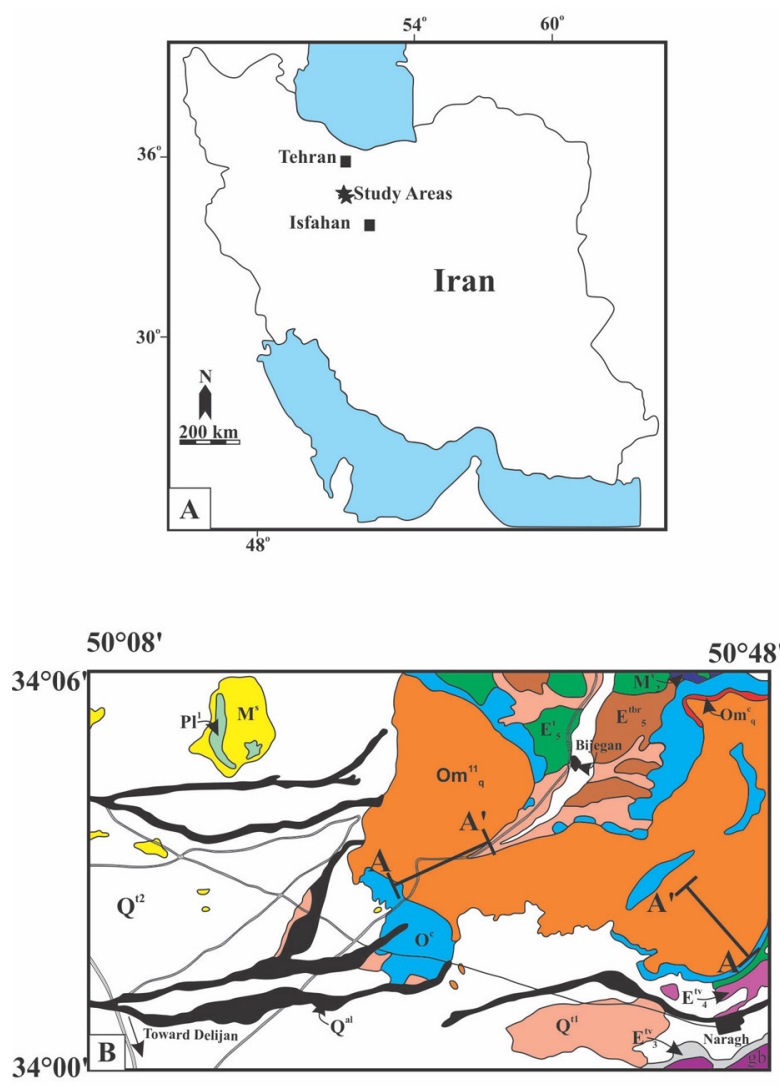

$$
\begin{aligned}
& \text { Path road } \\
& =\text { Main road } \\
& \text { AA' }^{\prime} \text { : Study section }
\end{aligned}
$$

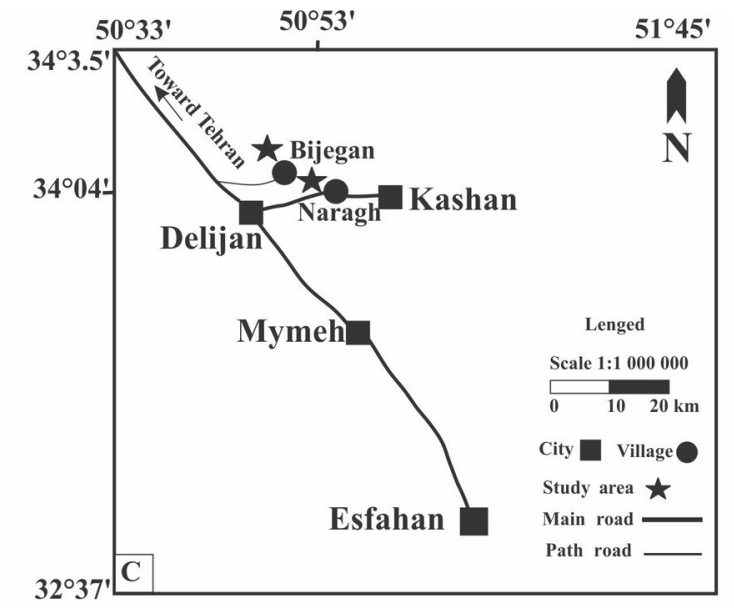

Legend

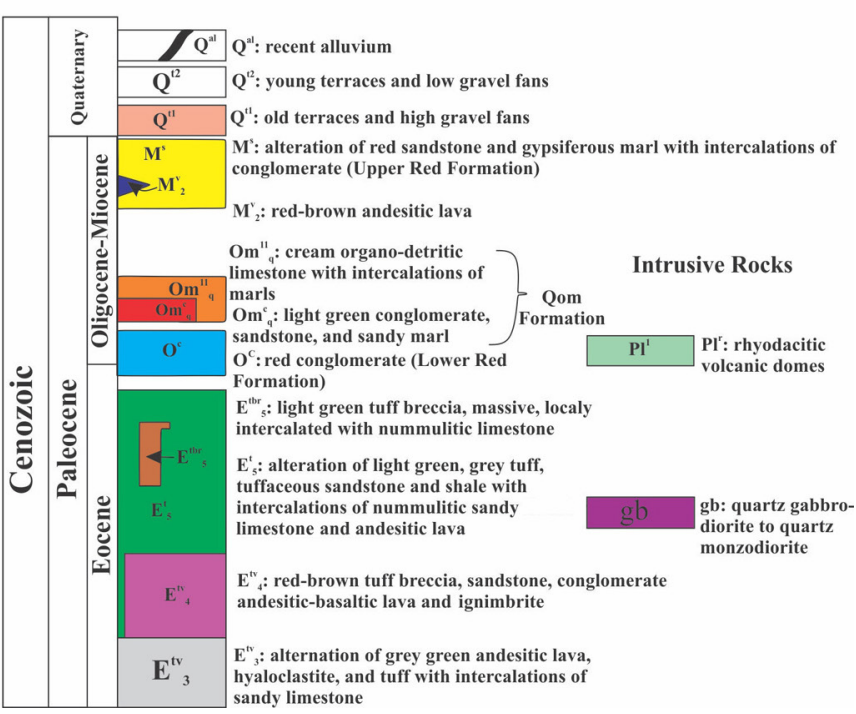

Fig. 2. A - Map of Iran, showing the position of the study areas (after Esrafili-Dizaji \& Rahimpour-Bonab, 2013); B - Geological map of the study areas to the northeast of Delijan (after Ghalamghash \& Babakhani, 1996); C - Road map of the study areas to the northeast of Delijan

era (walls on both sides) were undamaged, (1) the outer wall of the tests (large benthic foraminifera) was damaged on one side, (2) tests of large benthic foraminifera (outer wall) damaged on one or both sides (especially poles of test) and (3) tests broken into fine (sand and silt) fractions and heavily damaged.

\section{Previous work}

Initially, the Qom Formation was studied by Loftus (1854). Subsequent authors have identified a few members within this formation and correlated these with the Asmari Formation in southern Iran (Zagros Mountains), as based on palaeontological characteristics (Dozy, 1944; Furrer \& Soder, 1955; Abaie et al., 1964; Bozorgnia, 1966) (Fig. 3). The Qom Formation encompasses three sedimentary cycles, each beginning with limestone and ending with evaporites (Nogole-Sadat, 1985). Recent research has suggested that the Qom Formation represented deposition on an open-shelf platform in the Qom and Kashan areas (Mohammadi et al., 2011; Seddighi et al., 2011). However, six microfacies and two non-carbonate facies, as well as a ramp platform environment, were recognised in the Barzok area by Mohammadi et al. (2018). Moreover, Mohammadi et al. (2013) had earlier shown that the transgression had a southeast-northwest trend in the Qom Basin during the Rupelian to Burdigalian. 


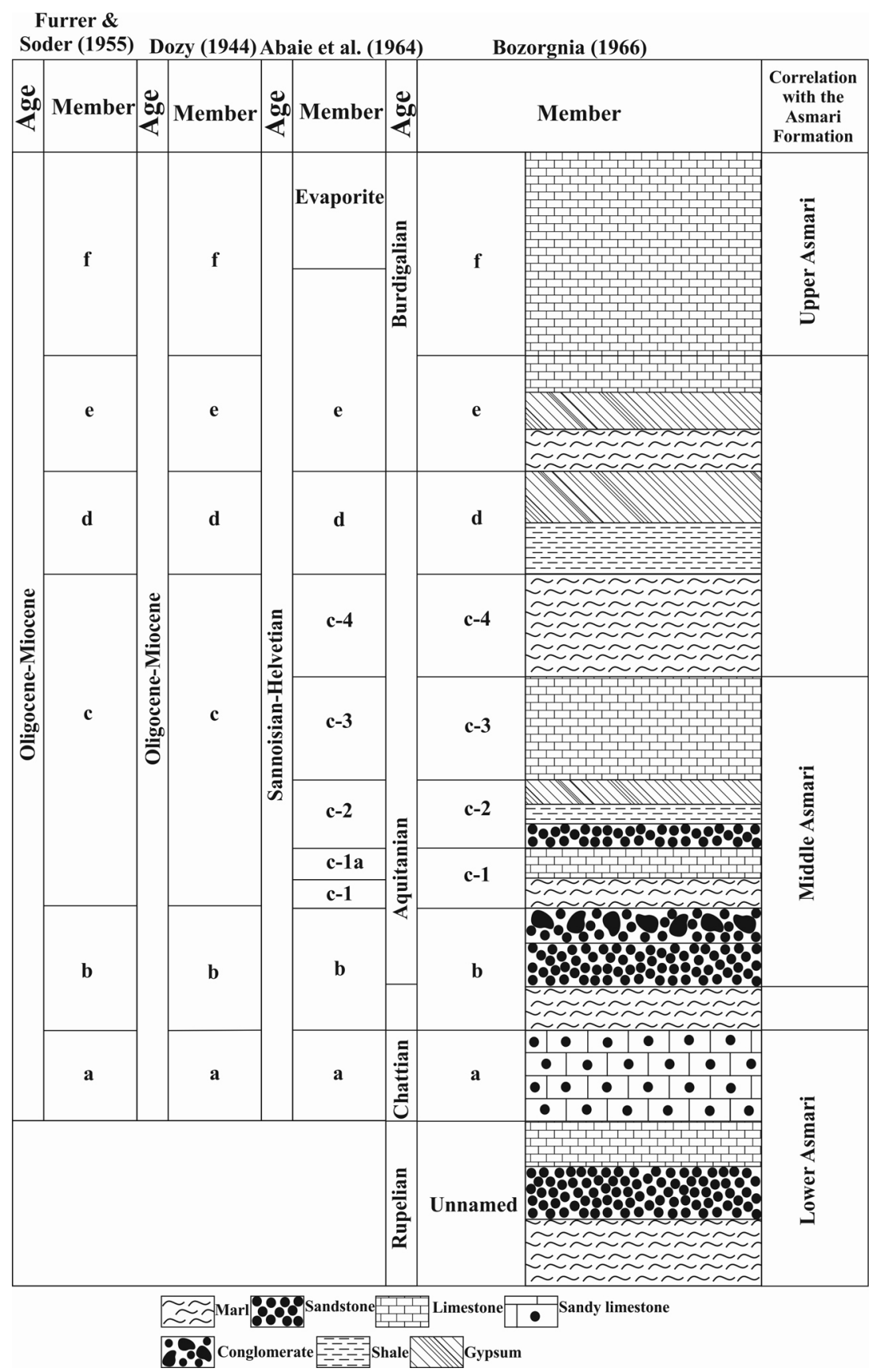

Fig. 3. Members of the Qom Formation (after Daneshian \& Ramezani Dana, 2007; Aghanabati, 2006)

\section{Results}

\subsection{Microfacies analysis}

Seven microfacies have been recognised in the study areas on the basis of petrography, sedimentological features, relative abundance of characteristic components and faunal elements represented; these are summarised in the following sections (Fig. 4).
5.1.2. Microfacies in the Naragh area

Sandy bioclast wackestone-packstone (MF 1), yielding miliolids, bryozoans, gastropods and siliciclasts (fine-sized quartz grains and glauconite) dominate in the Naragh area. Among imperforate foraminifera, miliolids and members of the genera Borelis, Peneroplis and Austrotrillina are the main components of the MF2 wackestone-packstone. Minor components of this microfacies are Elphidium, Textularia and ostracods. Imperforate (miliolids, 

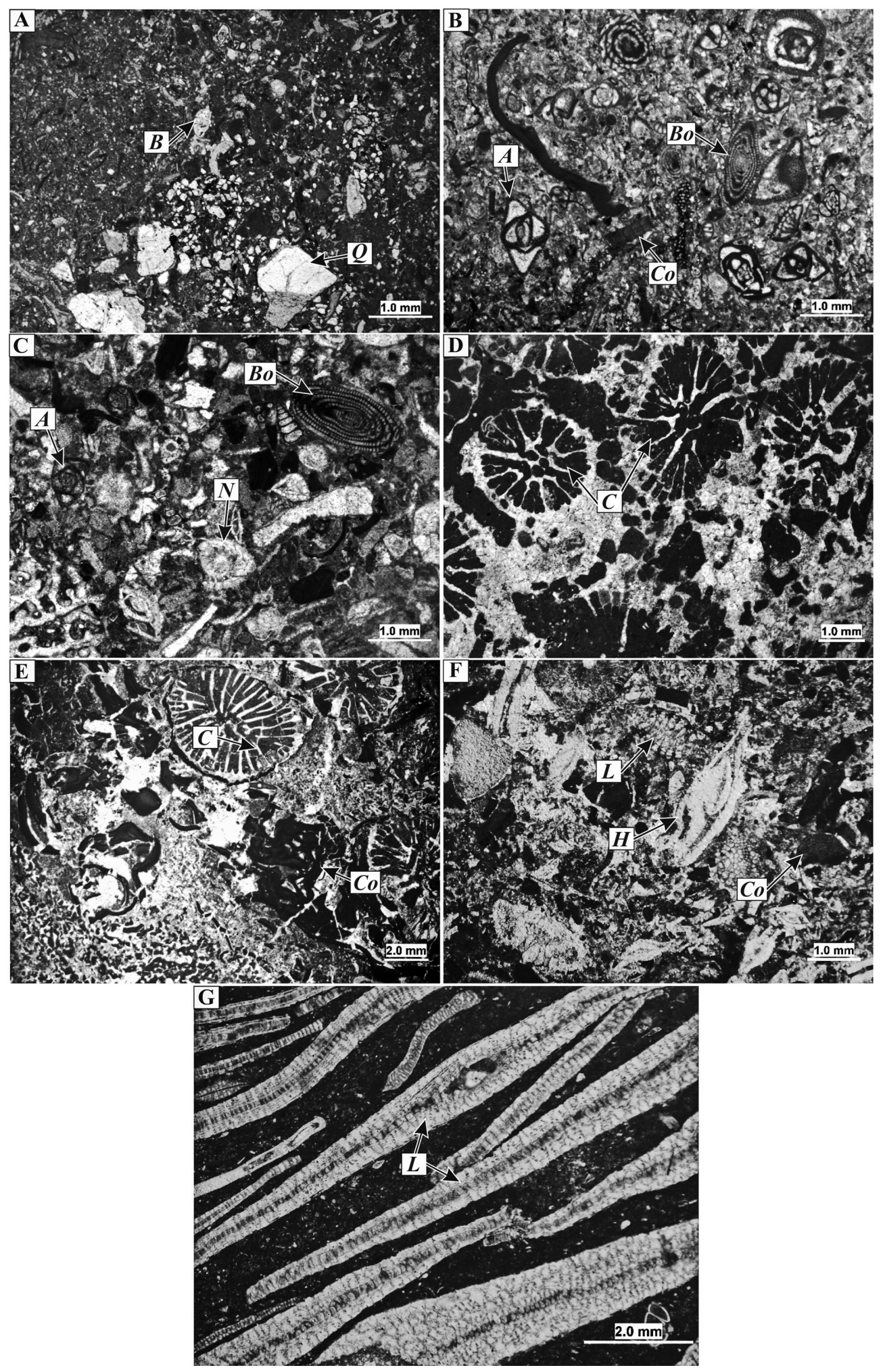

Fig. 4. Microfacies types of the Qom Formation

A - Sandy bioclast wackestone-packstone- grainstone, B: Bioclast; Q: Quartz grain; B - Bioclast imperforate foraminiferal wackestone-packstone, A: Austrotrillina, Bo: Borelis, Co: coralline red algae; C - Bioclast perforate-imperforate foraminiferal wackestone-packstone-grainstone, A: Austrotrillina; Bo: Borelis; N: Neorotalia; D - Coral boundstone, C: Coral; E - Corrallinaceae-coral packstone-rudstone, C: Coral; Co: Corallinaceae; F - Corallinaceae perforate foraminiferal packstone-grainstone (rudstone), H: Heterostegina; Co: Corallinaceae; L: Lepidocyclina; G - Bioclast perforate foraminiferal wackestone-packstone- grainstone, L: Lepidocyclina 

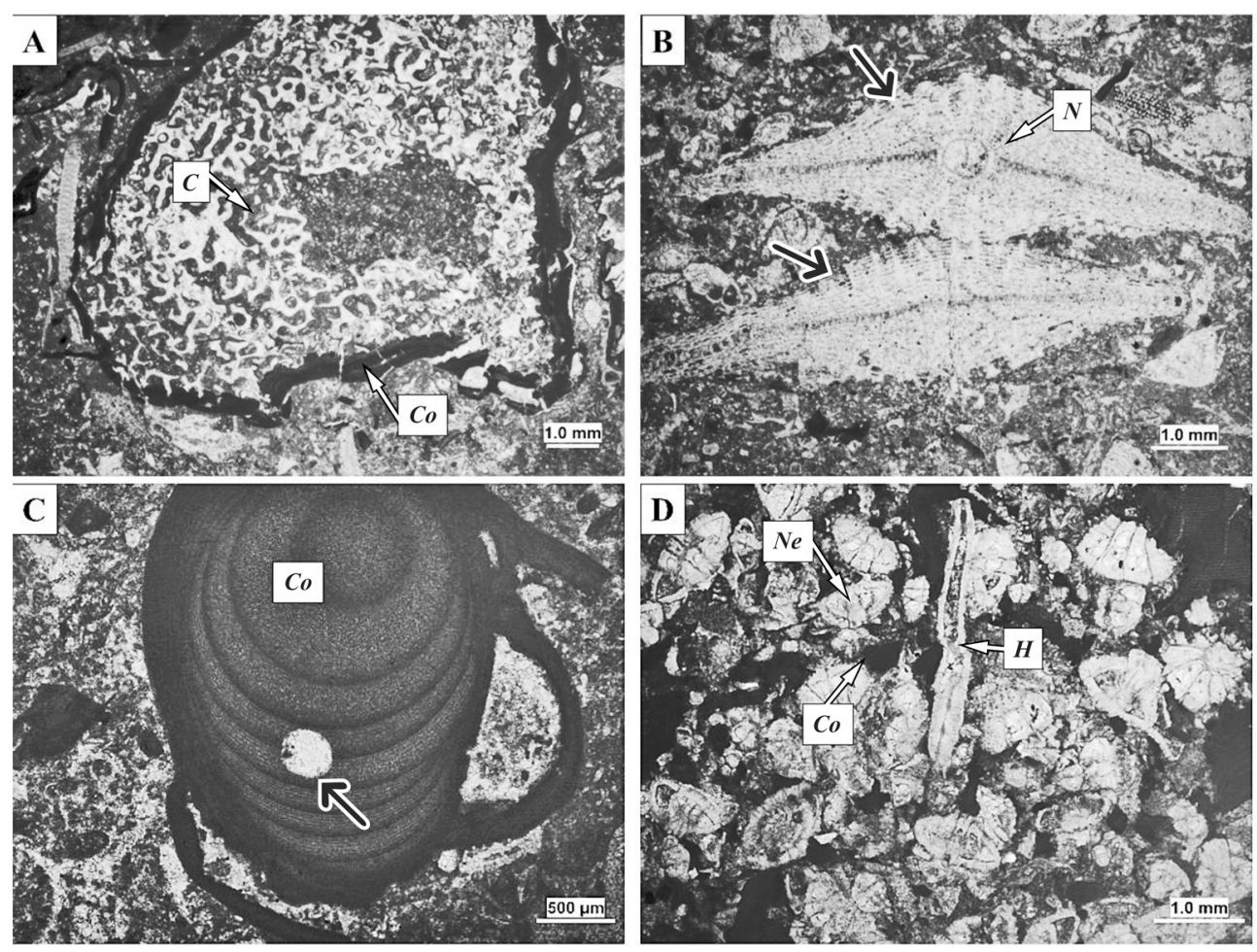

Fig. 5. Taphonomic signatures

A - Encrustation: coralline algal crust on a previously bored coral, C: coral, Co: Corallinacean algae; B - Abrasion: abrasion of outer wall of Lepidocyclinidae (black arrows), N: Nephrolepidina; C - Bioerosion: Holes drilled in corallinacean algae (black arrows), Co: Corallinacean algae; D - Fragmentation: fragmented pieces of various taxa (Co: Corallinacean algae, H: Heterostegina, Ne: Neorotalia)

Austrotrillina, Peneroplis and Borelis) and perforate foraminifera (Amphistegina, Lepidocyclina and $\mathrm{Ne}$ orotalia) are abundant in bioclast perforate/imperforate foraminiferal wackestone-packstone (MF 3). Debris of coralline red algae, corals, echinoids and bryozoans are rarely observed in microfacies 3 . Coral patch reefs (coral boundstone, MF 4) are present in the Naragh area and miliolids, Corallinaceae, echinoids and Elphidium are subordinate components. Taphonomic signatures (fragmentation, encrustation, disarticulation and bioerosion) are not observed in this study area. Bioclast coral-Corrallinaceae packstone-rudstone (MF 5) is composed mainly of coralline red algae and corals (large fragments). Subordinate components in this microfacies include miliolids, Neorotalia, Amphistegina and debris bioclasts (bivalves and other molluscs, echinoids). In the Naragh area, fragmentation and disarticulation rates are low to moderate. Abrasion of the outer walls of corals and bioerosion is of a low rate. Encrustation is abundant and consists of thin corallinacean algal crusts $(<1 \mathrm{~mm})$. Corallinaceae/ perforate foraminifera wackestone-packstone (rudstone) mainly includes coralline red algae and perforate foraminifera (Neorotalia and Lepidocyclina).
In microfacies MF 6, debris of echinoids, miliolids and Amphistegina are subordinate components. In the Naragh area, fragmentation and abrasion in this microfacies is high and the outer test wall of the large benthic foraminifera is damaged on both sides (Category 2). Encrustation and bioerosion are low. In the Naragh area, owing to changes in the type of fauna in some thin sections, the name of this microfacies changes to Neorotalia bioclast packstone. Bioclast perforate foraminifera wackestone-packstone (MF 7) consists of members of the family Lepidocyclinidae. Fragments of coralline red algae, corals, echinoids and bryozoans are scattered in this microfacies. In the Naragh area, the abrasion in large benthic foraminifera is high and the outer test wall of large benthic foraminifera is damaged on both sides (Category 2).

\subsubsection{Microfacies in the Bijegan area}

Sandy bioclast packstone-grainstone (MF 1) is composed of miliolids, Borelis, Austrotrillina, coralline algae and siliciclasts (fine-sized quartz grains); grains of detrital quartz are scattered in a micritic groundmass. The major components of the bioclast imperforate foraminiferal wackestone-packstone 
(MF 2) are miliolids (Quinqueloculina, Triloculina), Dendritina, Borelis, Peneroplis, Meandropsina and Austrotrillina, while minor elements include molluscan debris. However, the MF 2 contains debris of coralline red algae and fine-sized quartz grains in the Bijegan area. Abundant components of the bioclast corallinaceae perforate-imperforate foraminiferal packstone-grainstone $(\mathrm{MF} 3)$ include porcellaneous foraminifera such as miliolids, Austrotrillina, Dendritina, Peneroplis and Borelis as well as hyaline foraminifera (Amphistegina, Lepidocyclina, Operculina and Neorotalia). This microfacies is composed of subordinate components such as agglutinated foraminifera (Textularia, Meandropsina and a valvulinid) and fragments of coralline red algae, corals, echinoids and bryozoans. Fragmentation, disarticulation and abrasion rates in this microfacies are moderate to high. Low-moderate and low rates can be observed for bioerosion and encrustation, respectively. The coral boundstone (MF 4) contains corals and subordinate components of Corallinaceae and echinoids. This microfacies includes some patch reef in the study area. Taphonomic signatures (fragmentation, encrustation, disarticulation and bioerosion) are absent in this microfacies. Abundant red algae and corals are the main components in the Corallinaceae-coral packstone-rudstone (MF 5). Coral and coralline algal taxa fragments occur as large pieces (>1 mm). In the Bijegan area, taphonomic signatures such as fragmentation, encrustation and disarticulation rates are moderate to high. The bioerosion is low to moderate here. It contains other subordinate components such as miliolids, Lepidocyclina, Operculina and Heterostegina. The Corallinaceae perforate foraminiferal packstone-grainstone (rudstone) (MF 6) contains major components such as coralline red algae and perforate foraminifera (Neorotalia, Lepidocyclina, Operculina, Heterostegina, Nummulites and Amphistegina). In the Bijegan area, low to moderate rates of encrustation and bioerosion are noted, while fragmentation, disarticulation and abrasion rates are moderate to high. Tests of large benthic foraminifera (outer wall) damaged on one or two sides and at the poles of tests are missing from the Bijegan area (Categories 1 and 2). Other subordinate components include debris of echinoids, miliolids, Amphistegina and bryozoans. The bioclast perforate foraminiferal wackestone-packstone-grainstone (MF 7) contains an association of larger benthic perforate foraminifera (Lepidocyclinidae, Heterostegina, Operculina and Amphistegina). Tests of large benthic foraminifera (damaged on both sides as well as broken into fine grain) can be observed in the Bijegan area (Categories 2 and 3 ).

\section{Discussion}

\subsection{Microfacies interpretation and distribution on platform}

On the basis of sedimentological (vertical microfacies relationships) and palaeontological data (distribution of foraminifera), the Qom succession represents deposition on an open-shelf platform (Figs 6-8). The platform can be divided into inner shelf and middle shelf depositional environments.

Deposits of the restricted and semi-restricted lagoons formed in an inner shelf environment. Microfacies such as the sandy bioclast wackestone-packstone-grainstone (MF 1) and bioclast imperforate foraminifera wackestone-packstone (MF 2) belong to the restricted lagoon. The abundance of miliolids, gastropods as well as fine-sized quartz grains indicate that deposition of the MF1 microfacies took place in shallower and more shoreward parts with low water circulation and a high level of salinity (lagoon) (Romero et al., 2002; Wilson \& Evans, 2002). According to Flügel (2010) and Pomar et al. (2015), the presence of carbonate and siliciclastic materials indicate a shallow subtidal (coastal shallow waters) setting and an abundance of swamps in a shallow lagoon. Similar microfacies, with MF1, are known from the Miocene sequence of the Asmari and Qom formations (Allahkarampour Dill et al., 2010; Mohammadi et al., 2011). The restricted lagoonal environment was recognised on the basis of an abundance of imperforate foraminifera (e.g., Peneroplis and miliolids) by Geel (2000), Romero et al. (2002) and Schmidt et al. (2011). Miliolids live in shallow water (low turbulence water) and, together with Alveolinidae, indicate seagrass meadows (Geel, 2000; Murray, 2006; Tomassetti et al., 2016). In addition to this, the presence of Peneroplis in the MF 2 microfacies is indicative of tropical and subtropical shallow environments (Lee, 1990; Brandano et al., 2010). Imperforate foraminifera (e.g., peneroplids and miliolids) have been reported from hypersaline environments (>50 psu) (Brandano et al., 2009; Mossadegh et al., 2009; Flügel, 2010) and imperforate foraminifers are abundant in settings with euphotic and eutrophic conditions (Pomar, 2001; Romero et al., 2002; Renema, 2002; Beavington-Penney \& Racey, 2004). The open lagoon environment is characterised by bioclast perforate-imperforate foraminiferal wackestone-packstone-grainstone (MF 3) and coral boundstone (MF 4 ). The occurrence of imperforate (miliolids, Austrotrillina, Peneroplis and Borelis) and perforate (Amphistegina, Operculina and Neorotalia) foraminifera indicates a semi-restricted lagoonal setting with a 
seagrass substrate (Beavington-Penney et al., 2006; Afzal et al., 2011; Nebelsick et al., 2013). Imperforate foraminifera live in shallow environments (restricted lagoon), while perforate and imperforate benthic foraminifera are found in semi-restricted lagoons (Geel, 2000; Romero et al., 2002). Agglutinated foraminifera also represent a shallow-water lagoon and open-marine environment for the MF 3 microfacies (Geel, 2000). Pomar et al. (2014) believed that benthic foraminifera such as large imperforate foraminifera, miliolids and Amphistegi$n a$, inhabited the euphotic zone. Amirshahkarami et al. (2007) reported similar microfacies from the Chaman-Bolbol in the Zagros Basin of Iran. The coral fauna of the study area (MF 4 microfacies) occurs in small patch reefs. The MF 4 microfacies is equivalent to the standard microfacies (SMF 6) introduced by Flüugel (2010) and is related to reef deposition. Mohmmadi et al. (2011) believed that these corals were related to lagoonal patch reefs. Riegl et al. (2010) and Beresi et al. (2016) showed that patch reefs were abundant in lagoonal environments with high levels of salinity and influx of siliciclastics. A similar microfacies was reported for the Qom Formation to the south of Kashan (Mohammadi et al., 2011), $27 \mathrm{~km}$ from the city of Qom (Seddighi et al., 2011) and by Amirshahkarami et al. (2007) from the Asmari Formation.

The middle shelf environment is composed of Corallinaceae-coral packstone-rudstone (MF 5), Corallinaceae perforate foraminifera packstone-grainstone (rudstone) (MF 6) and bioclast perforate foraminiferal wackestone-packstone-grainstone (MF 7). Proximal middle shelf environmental and mesophotic to oligophotic conditions are characterised by an abundance of larger benthic perforate foraminifera (Neorotalia and Lepidocyclina), red algae and corals (Pomar, 2001; Brandano et al., 2016;

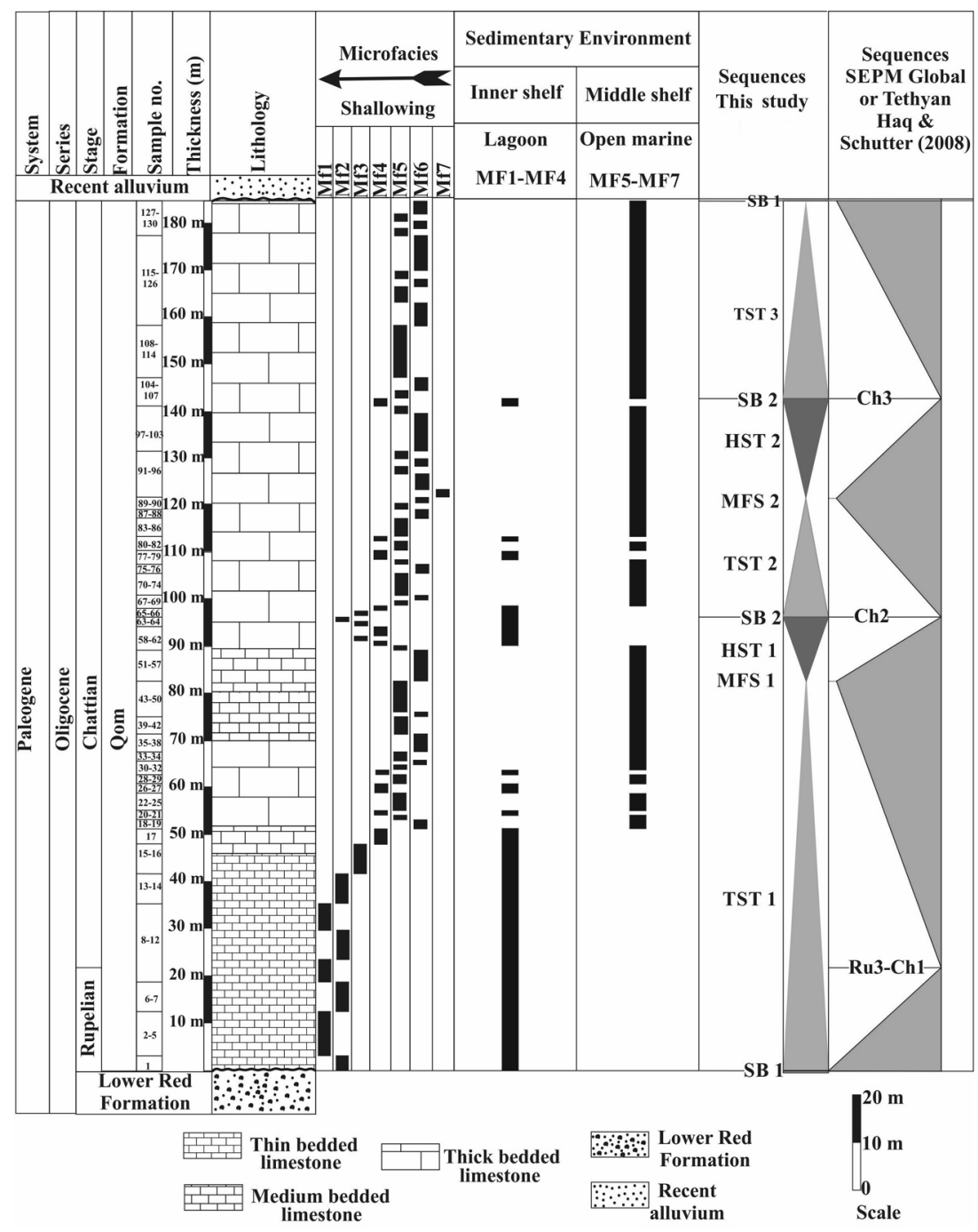

Fig. 6. Vertical microfacies distribution and sequences of the Qom Formation in the Naragh area (northeast of Delijan), central Iran and correlation with Haq \& Schuttter (2008) 
Pomar et al., 2017; Sarkar, 2017). The occurrence of coralline algae in the MF 5 microfacies indicates mesophotic-oligophotic and shallow-water conditions (Pomar et al., 2014) and confirms the occurrence of seagrass meadows (Beavington-Penney et al., 2004). In addition, red algae thrive in euphotic to oligophotic zones, where photic levels are elevated (Kovacs \& Arnaud-Vanneau, 2004; Pomar et al., 2014). The grain-supported matrix of the MF 5 microfacies represents moderate to high-energy conditions, near and below the fair-water wave base on the proximal middle shelf for that microfacies (Pomar, 2001; Flügel, 2010). Nebelsick et al. (2000, 2001), Loffler \& Nebelsick (2001) and Schmiedl et al. (2002) reported similar microfacies from the Paratethys Basin. The occurrence of cor-

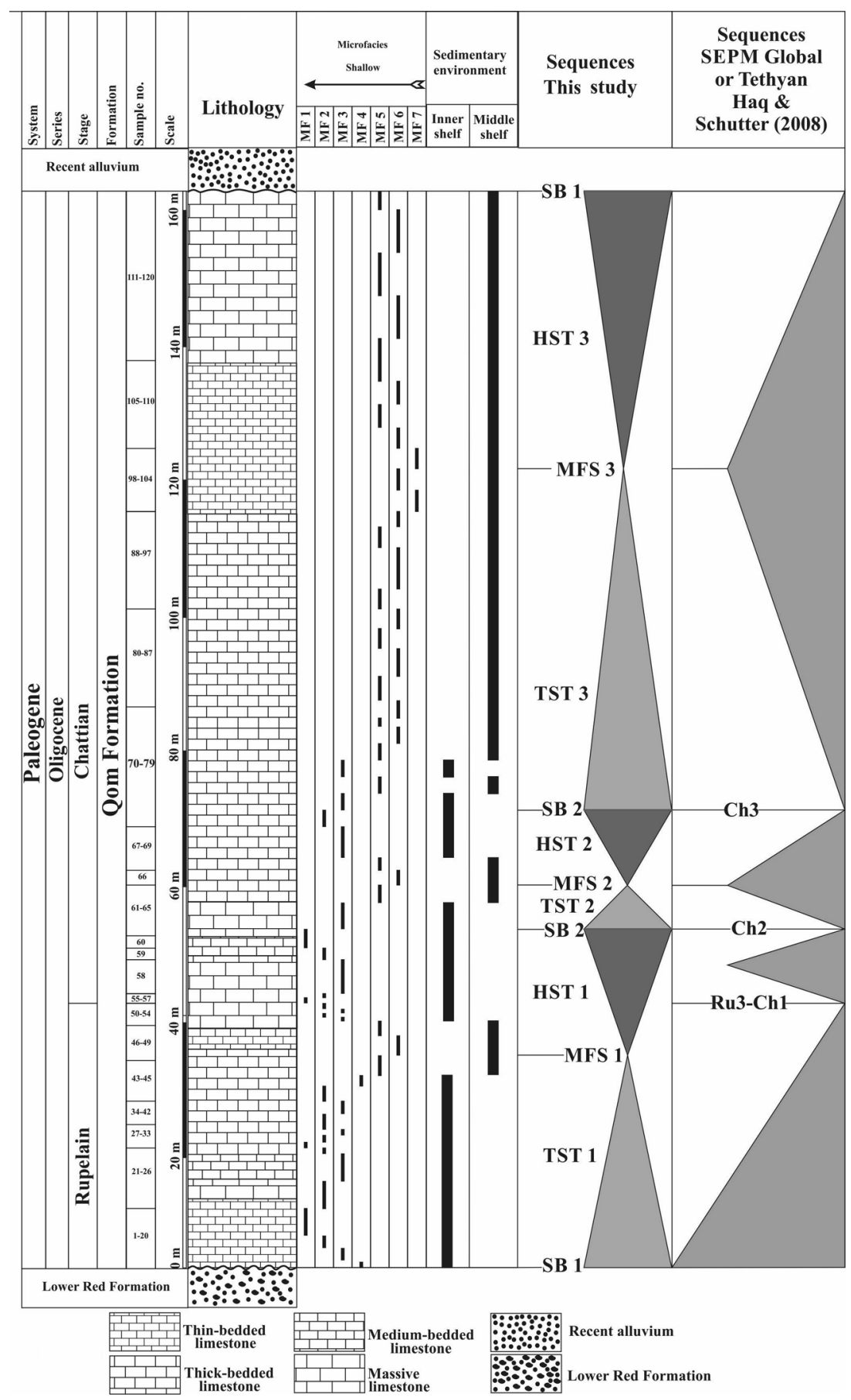

Fig. 7. Vertical microfacies distribution and sequences of the Qom Formation in the Bijegan area northeast of Delijan), central Iran and correlation with Haq \& Schuttter (2008). 
alline algae and perforate foraminifera indicates mesophotic to oligophotic zones, and normal marine salinity conditions for the MF 6 microfacies (Corda \& Brandano, 2003). In addition, red algae are abundant in the open-marine middle shelf environment and under eutrophic conditions (Basso, 1988, Halfar \& Mutti, 2005; Bassi et al., 2007). The grain-supported matrix with an abundance of red algae and hyaline foraminifera indicates moderate to high-energy conditions as well as near and below fair-water wave base on the proximal middle shelf for the MF 6 microfacies (Pomar, 2001; Flügel, 2010). Amirshahkarami et al. (2007) and Nebelsick et al. (2001) reported similar microfacies from the Chaman-Bolbol in the Zagros Basin of Iran, and from the Paratethys, respectively. The presence of larger benthic foraminifera in the MF 7 microfacies indicates low-medium energy, an open-marine environment, below fair-water wave base (Hottinger, 1997; Pomar, 2001; Romero et al., 2002; Flügel, 2010). The MF 7 microfacies was deposited in the lower photic or oligophotic zone and this interpretation is supported by the abundance of larger symbiotic foraminifera (Lepidocyclina) (Geel, 2000, Pomar, 2001, Romero et al., 2002; Renema, 2006; Bassi et al., 2007). A similar microfacies from the Chaman-Bolbol in the Zagros Basin of Iran has been reported by Amirshahkarami et al. (2007). Fragmentation and disarticulation rates resulting from seawater depth and wave base are moderate to high, indicating high to very high-energetic environments
(Nebelsick et al., 2011; Silvestri et al., 2011). Silvestri et al. (2011) believed that coralline red algae and corals were fragmented and abraded by transport and reworking. High rates of encrustation can be observed in an environment with high energy and a low sedimentation rate (Silvestri et al., 2011; Ćosović et al., 2012; Bover-Arnal et al., 2017). The tests of large benthic foraminifera were damaged by wave action, which transported them to distant location (Beavington-Penny, 2004). The abundance of large benthic foraminifera with a damaged outer wall indicates extensive and turbidity-current transport with wave reworking (Beavington-Penny, 2004). Tests of large benthic foraminifera were broken into fine fragments by high-energy waves (Ćosović et al., 2012). In the Bijegan area, taphonomic signatures (fragmentation, disarticulation and abrasion) in MF 3 show that this microfacies formed in a high to very high-energy setting, above fair-weather wave base. In the Naragh area, the encrustation rate of the MF 5 is indicative of an environment with high energy and a low rate of sedimentation. However, the rate of other taphonomic signatures such as fragmentation and disarticulation suggests moderate energy for the sedimentary environment of MF 5. Fragmentation, disarticulation and encrustation rates in the Bijegan area indicate that the water energy and rate of sedimentation were lower than the Naragh area for MF 5. MF 6 in the Naragh area formed in an environment with high water energy (more than in the Bijegan area), as based on tapho-

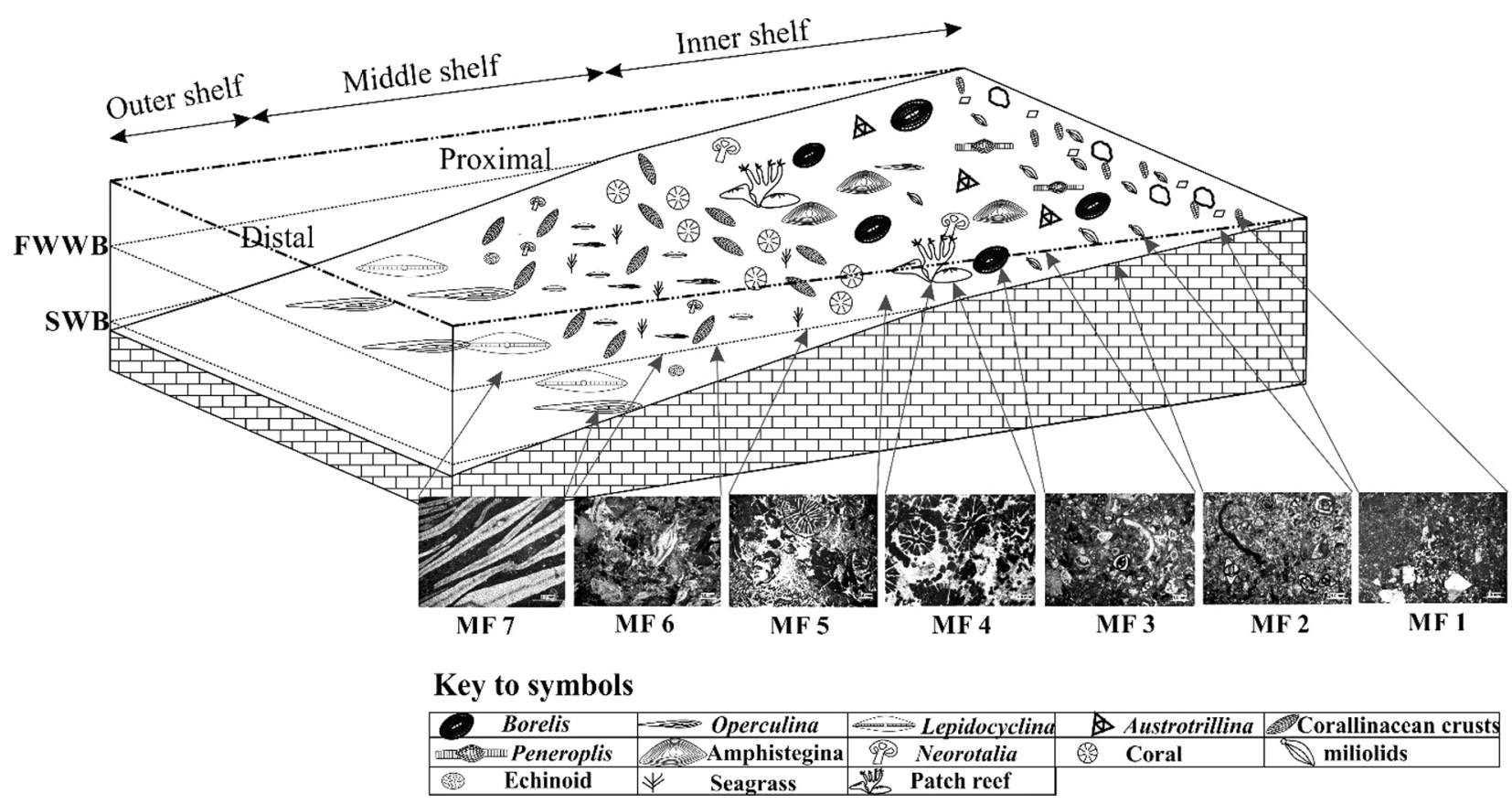

Fig. 8. Depositional model for platform carbonates of the Qom Formation in the Naragh and Bijegan areas (northeast of Delijan), central Iran 
nomic signature rates and damage rates of large benthic foraminiferal tests. However, test damage (category) shows that the MF 7 in the Bijegan area was deposited in a setting with higher water energy than the one in the Naragh area.

\subsection{Sequence stratigraphy}

Three third-order depositional sequences, composed of TST (transgressive systems tracts), MFS (maximum flooding surface) and HST (highstand systems tracts), as well as an incomplete depositional sequence containing TST (transgressive systems tracts) have been recognised (Figs 6, 7).

- Sequence 1: This sequence in the Naragh area (thickness: $97 \mathrm{~m}$ ) and the Bijegan area (thickness: $57 \mathrm{~m}$ ) starts with lagoonal deposits (MF 2 and MF 4, respectively; see Figs 6, 7). This sequence consists of thin-, medium- and thick-bedded layers of limestones in both study areas. In the Naragh and Bijegan areas, an erosional surface (sequence

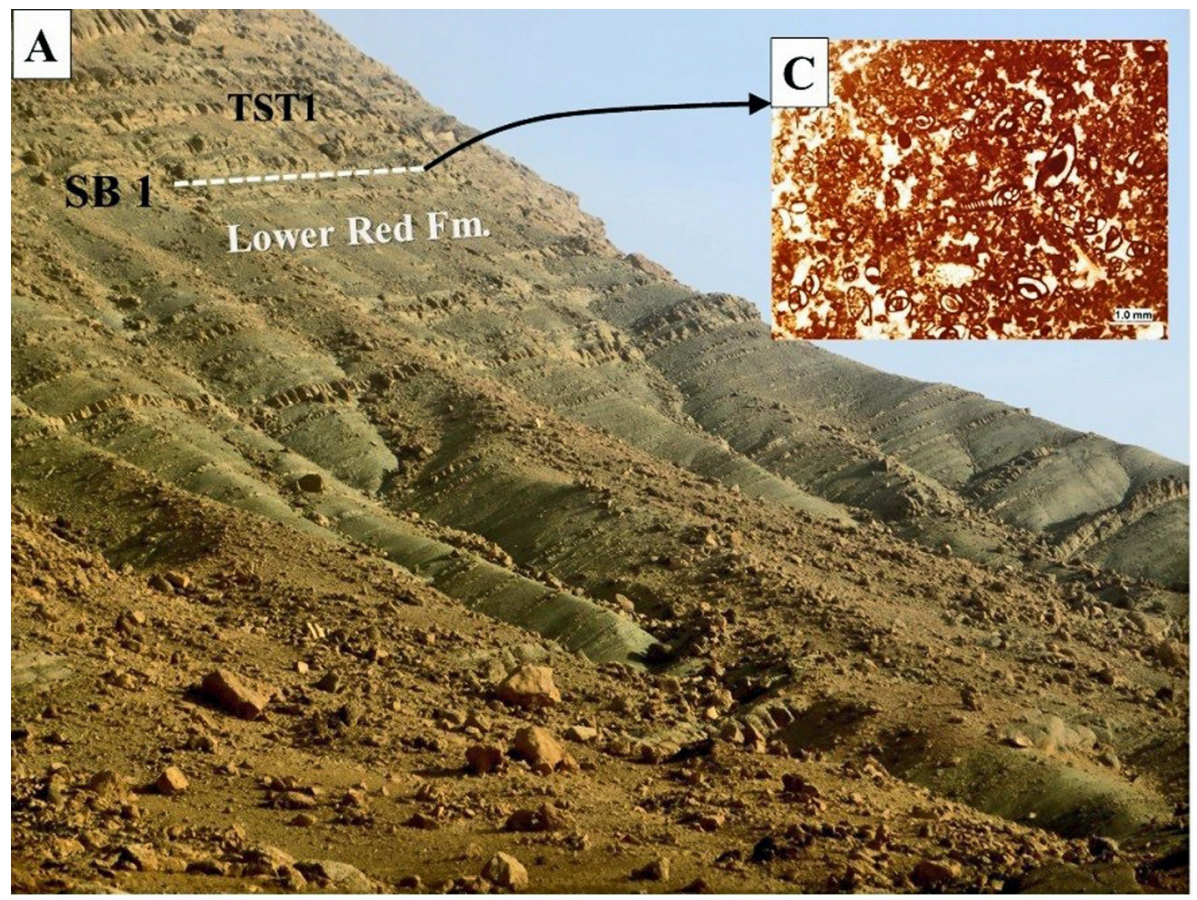

Fig. 9. A - Field photograph of sequence boundary between the Lower Red Formation and the Qom Formation in the Naragh area (northeast of Delijan); B - General view of the sequence boundary between the Lower Red Formation and the Qom Formation in the Bijegan area; C, D - Photomicrograph of the sequence boundary in the study areas; E - Field photograph of limestone layer belonging to the Qom Formation in the Bijegan area; D - Field photograph of conglomerate layer belonging to the Lower Red Formation in the Bijegan area

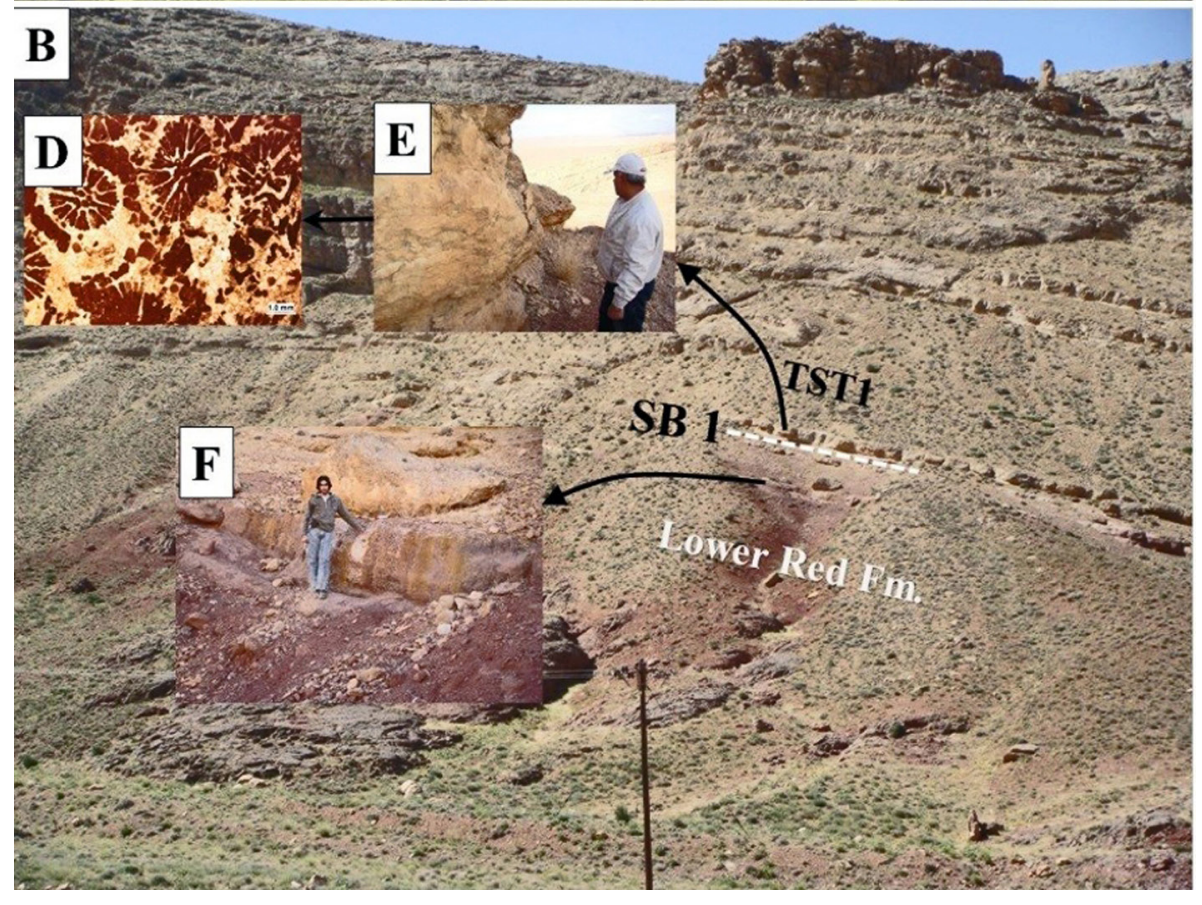


boundary of Type I) was observed between the Lower Red and Qom formations. In the Naragh area, transgressive systems tracts (TST) with an upward-deepening trend composed of limestone belongs to the lagoon and open-marine environments (Figs 6, 9). However, the transgressive systems tracts (TST) in the Bijegan area contains limestones of the lagoon and open-marine environments (Figs 7, 9). The limestones (containing Corallinaceae perforate foraminiferal packstone-grainstone (rudstone)) are indicative of the maximum flooding surface (MFS) in the Bijegan and Naragh areas (Fig. 10). In the Naragh area, the upper part of sequence 1 (HST) is characterised by medium- and thick-bedded limestone belonging to restricted lagoonal and to proxi- mal middle shelf environments (Figs 6, 10). HST (highstand systems tracts) in the Bijegan area is composed of thin, medium and thick limestone layers (Figs 7, 10). These limestones formed in restricted lagoonal to proximal middle shelf environments. The boundary between sequences 1 and 2 (sequence boundary of Type 2, SB 2) in the Naragh and Bijegan areas is characterised by imperforate foraminiferal wackestone-packstone (MF 2) and sandy bioclast wackestone-packstone-grainstone (MF 1), respectively. This sequence boundary appears to be correlatable with the sequence boundary Ch2 of Haq \& Schutter (2008) (Figs 6, 7).

- Sequence 2: In the Naragh area, this sequence, with a thickness of $46 \mathrm{~m}$, is composed mainly of
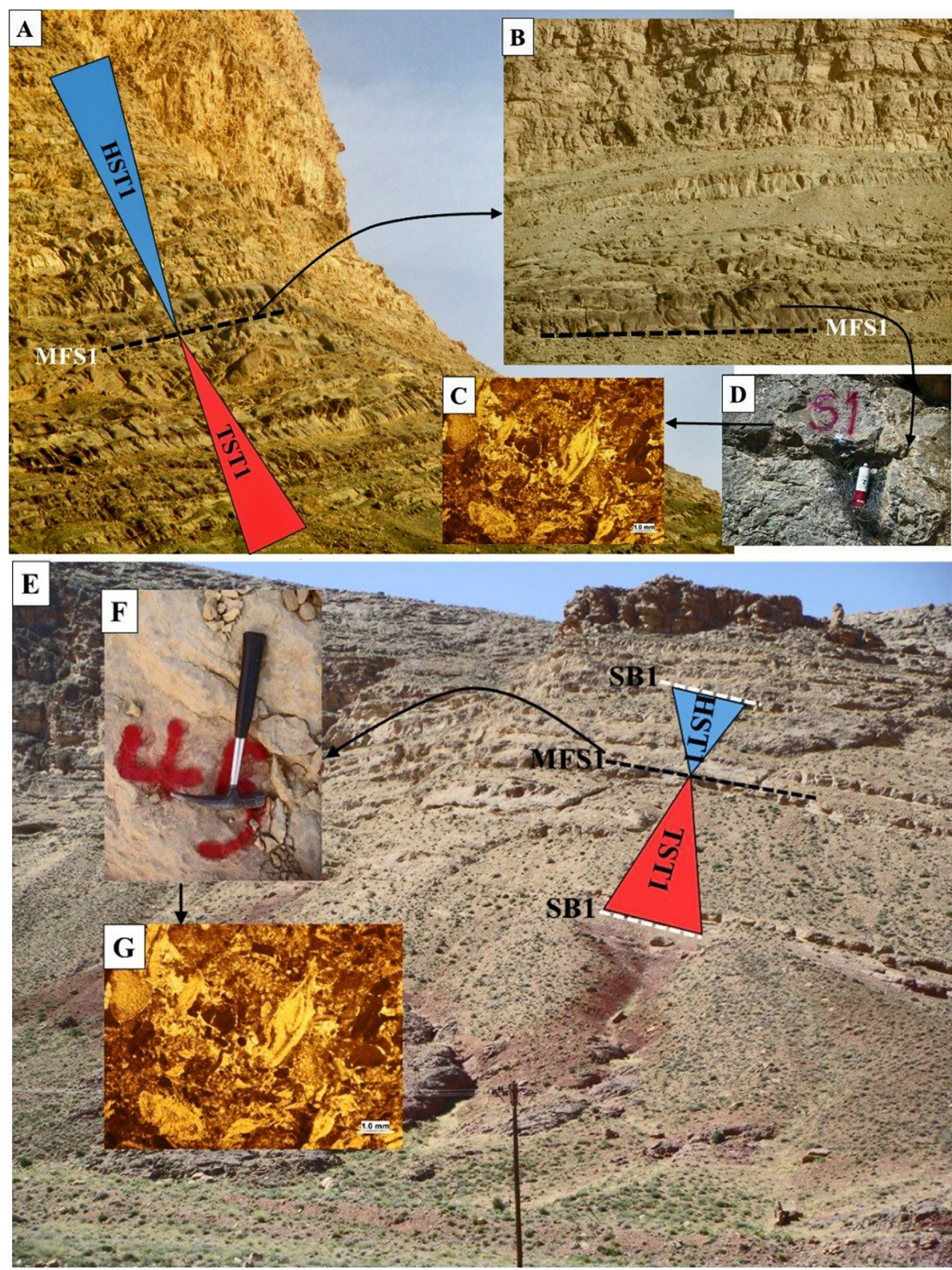

Fig. 10. A, E - Photograph of first depositional sequence in the study areas; A, D - Field views of the maximum flooding surface (MFS), TST and HST systems tract of sequence 1 in the Naragh area; $\mathbf{F}$ Field photograph of the maximum flooding surface (MFS), TST and HST systems tract of sequence 1 in the Bijegan area; C, G - Microscopic photographs of maximum flooding surface 1 in the study areas 
a succession of thin-, medium- and thick-bedded limestones. Layers of limestone (thick- and massively bedded) with a thickness of $15 \mathrm{~m}$ can be observed in sequence 2 in the Bijegan area. In both areas, the lower part of Sequence 2 is characterised by an upward- deepening trend (TST), which is marked by limestone of lagoonal and open-marine environments (Figs 6, 7, 11). In the Naragh area, the MFS is defined by the occurrence of thick-bedded limestone with large benthic foraminifera (Figs 6, 12). Medium-bedded limestone (containing coralline red algae and large perforate foraminifera) can be considered to constitue the MFS for this sequence in the Bijegan area (Figs 7, 12). Deposits of lagoonal and open-marine environments (medium- and thick-bedded limestone) are indicative of the highstand systems tracts (HST) in the Naragh and Bijegan areas (Figs 6, 7, 12). The sequence boundary of Type 2 (SB 2) between sequences
1 and 2 is characterised by patch reefs in the Naragh area (Figs 6, 13). In the Bijegan area, the same is marked by medium-bedded limestone of a restricted lagoon environment (Figs 7, 13). This sequence boundary seems to be correlatable with the sequence boundary Ch3 of Haq \& Schutter (2008) (Figs 6, 7).

- Sequence 3: In the Naragh area, this sequence is an incomplete depositional sequence and indicates an upward-deepening trend (transgressive systems tracts, TST) (Fig. 13). This package consists of thick-bedded limestone with numerous perforate foraminifera (Neorotalia and Lepidocycli$n a)$, corallinacean and coral debris in the Naragh area. The thickness of Sequence 3 is $42 \mathrm{~m}$; it is characterised by a thick-bedded limestone of an open-marine environment (containing large benthic foraminifera and coralline red algae) in the Naragh area (Figs 6, 13). However, in the Bijegan area this sequence is a third-order depositional

Fig. 11. A, E - Outcrop photograph of the sequence boundary between first and second depositional sequences in the study areas; B, C - Field photographs of the sequence boundary in the Naragh area; F - Field view of the sequence boundary in the Bijegan area; D, G - Photomicrographs of thin section of sequence boundary in the study areas
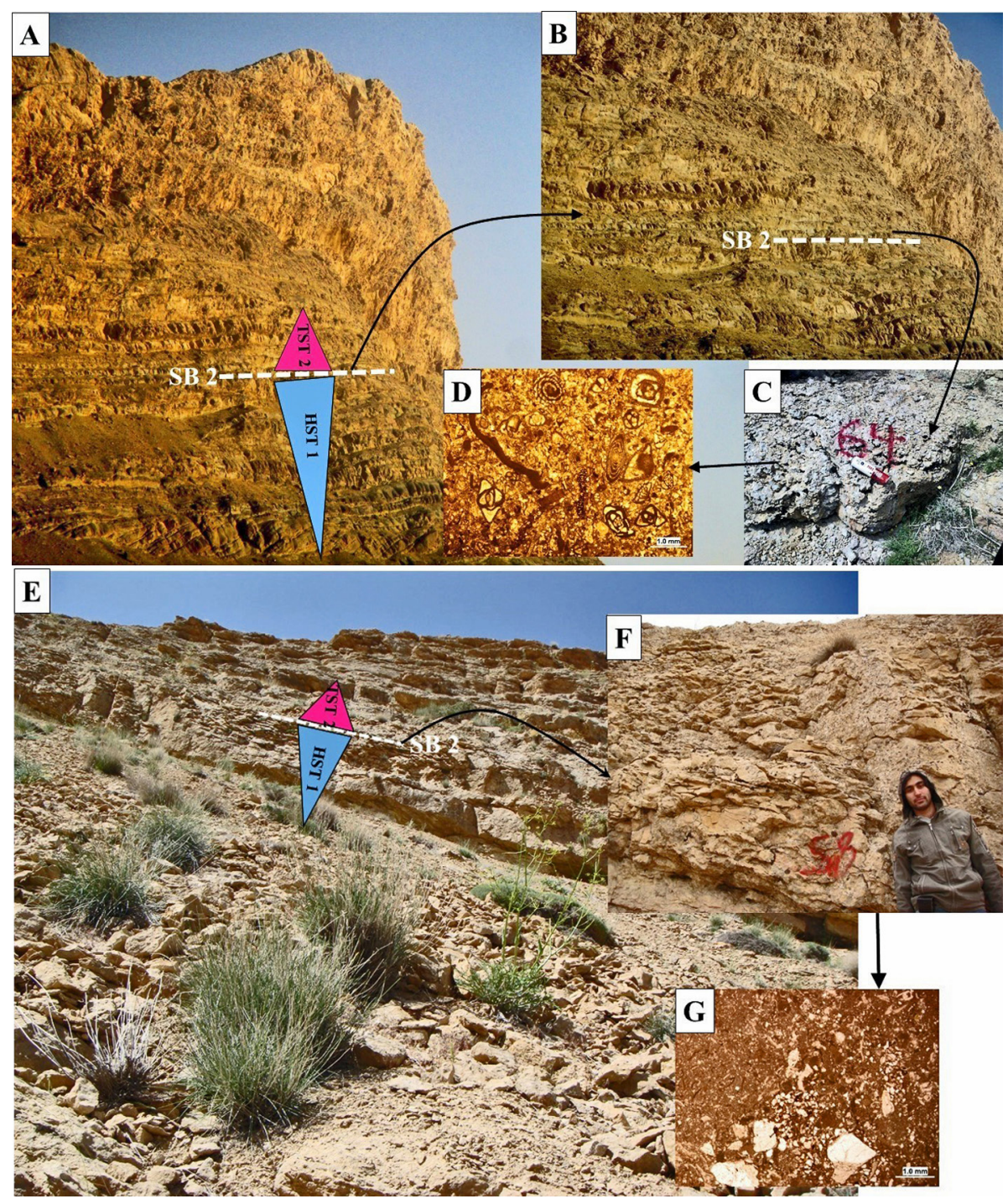


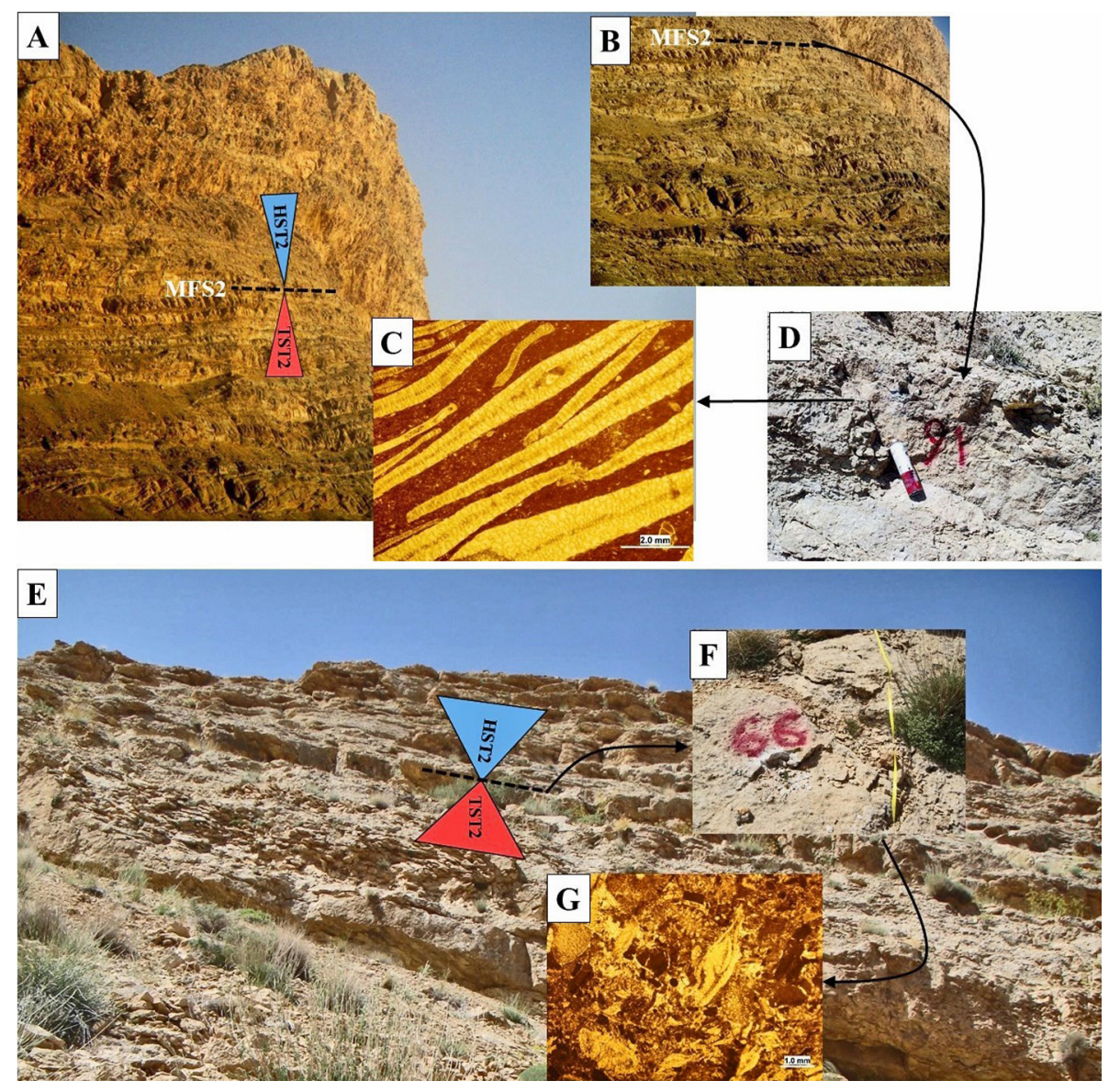

Fig. 12. A, E - General view of second depositional sequences (TST 2, MFS 2 and HST 2); B, D - Field photographs of maximum flooding surface (MFS) belonging to the second depositional sequences in the Naragh area; F - Field view of the maximum flooding surface (MFS) belonging to second depositional sequences in the Bijegan area; C, G - Photomicrographs of the thin section of maximum flooding surface (MFS 2) in the study areas

sequence. The sequence, of $90 \mathrm{~m}$ in thickness, starts with lagoonal deposits (medium-bedded limestone). The transgressive systems tracts (TST) of sequence 3 is composed of thin- and medium-bedded limestones of a lagoonal and open-marine environment (Figs 7, 13). The MFS is characterised by thin-bedded limestones (rich in large benthic foraminifera such as Lepidocyclina) (Figs 7, 13). Limestone of an open-marine environment (thin- and thick-bedded limestone) formed in highstand systems tracts (HST) (Figs 7, 13). The erosional surface (sequence boundary of Type I) was observed at the boundary between the Qom Formation and recent alluvial deposits in the Naragh and Bijegan areas.

\subsection{Correlation between depositional sequences of the northern and southern Tethyan seaway and Paratethys}

The influence of local fault activities and global sea level change on the distribution of depositional sequences in the Qom Basin (especially during the Rupelian-Chattian) is important. Morley et al.
(2009) showed that local fault activity increased in the Qom Basin during the Oligocene-Miocene. In fact, those researchers suggested that the rate of sedimentation and subsidence due to local fault activity were variable in different areas of the Qom Basin. In addition, a connection between the margins of the northern and southern Tethyan seaways and Paratethys Basin (trend: northwest to southeast) during the Rupelian-Chattian was documented. During the Rupelian and Chattian, three third-order depositional sequences in the Bijegan area and two third-order depositional sequences and an incomplete depositional sequence in the Naragh area formed (Figs 6, 7, 14). Mahyad et al. $(2018,2019)$, who studied the Oligocene and Miocene deposits of the Qom Formation, identified nine depositional sequences in the Kahak, Nowbaran and Andabad areas. Data published by Vakarcs et al. (1998), Ehrenberg et al. (2007), Haq \& Schutter (2008), van Buchem et al. (2010) and Mahyad et al. $(2018,2019)$ were used in the present research. The curve of the study areas was correlated to other basins (southern Tethyan seaway and Paratethys) and with the global sea level change (Fig. 14). During the Rupelian and Chattian, the study areas were affected by local faults to a higher extent than the 


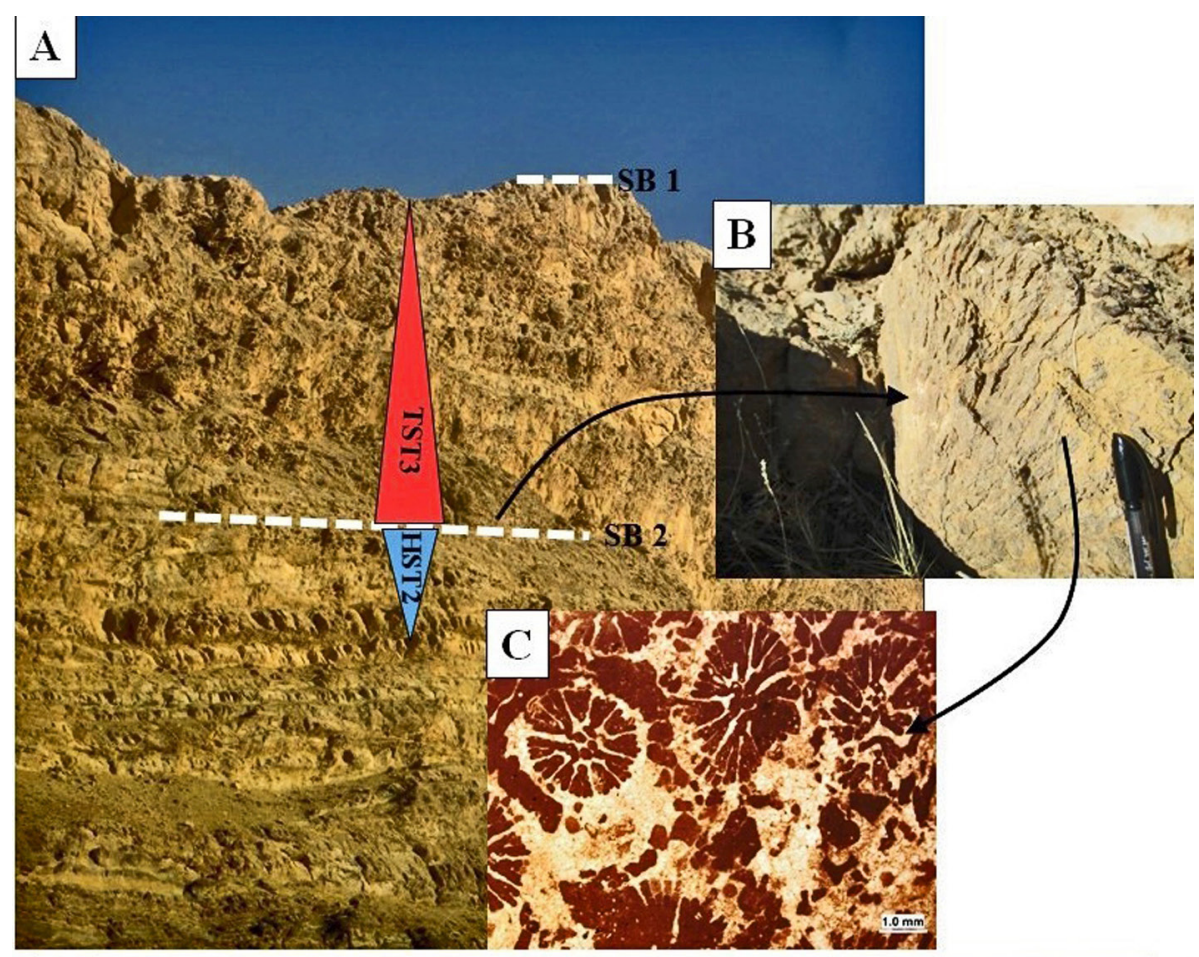

Fig. 13. A, D - Field views of the sequence boundary between second and third depositional sequences in the study areas; B Outcrop of the sequence boundary and third depositional sequence in the Naragh area; I - General view of the sequence boundary in the Bijegan area; C, H - Photomicrographs of the sequence boundary in the study areas; E, G - Outcrop photographs of the maximum flooding surface (MFS) of sequence 3 in the Bijegan area. F - Photomicrograph of the maximum flooding surface (MFS) of sequence 3 in the Bijegan area

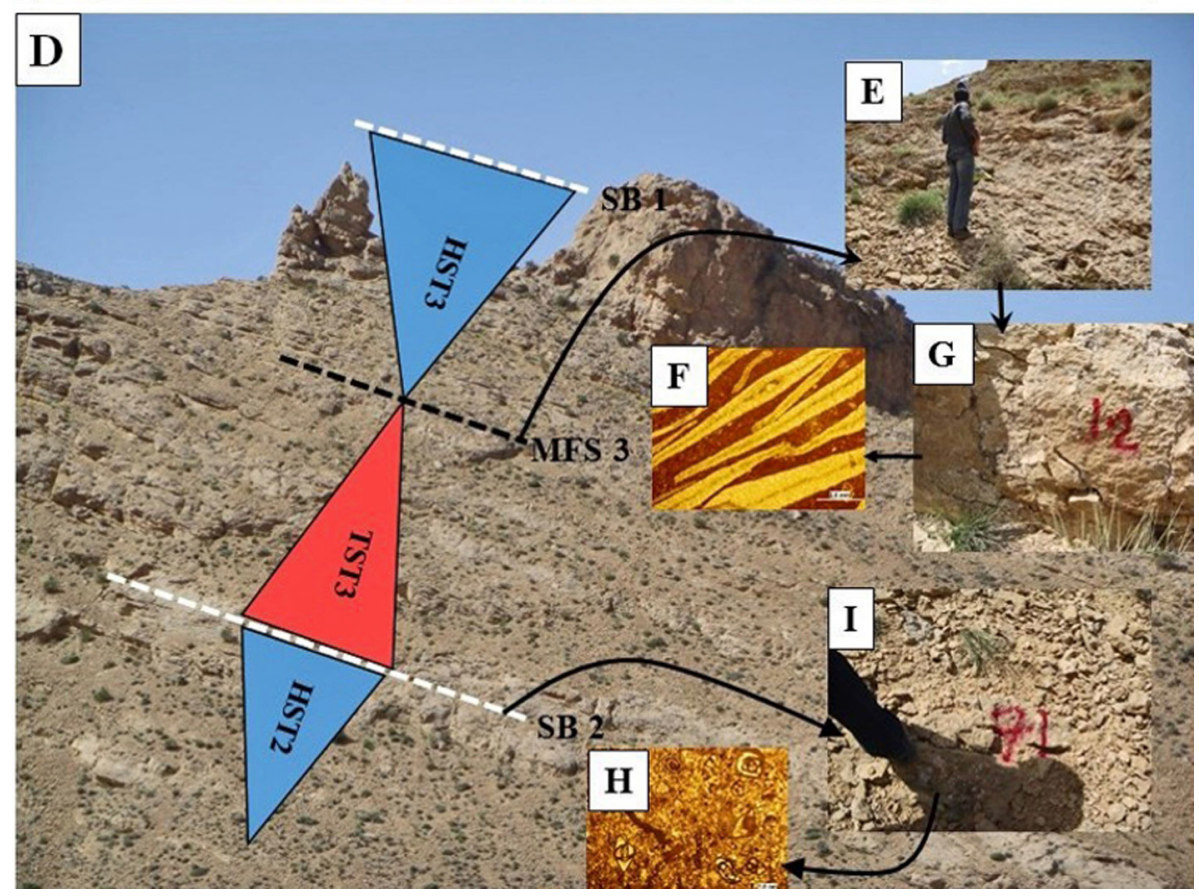

fluctuation of sea level of the southerb Tethyan seaway and Paratethys. In addition to this, Mahyad et al. (2019) indicated that a full connection between the Tethyan seaway and Paratethys basins occurred during the Burdigalian and suggested that this was discontinued during the late early Burdigalian (see Reuter et al., 2009). However, this connection continued to exist during the Langhian and early Serravallian (Rögl, 1997, 1999). Therefore, the depositional basins (southern Tethyan seaway, Paratethys and Qom Basin) of the Tethyan seaway were related both during the Burdigalian and later.

\section{Conclusions}

Two outcrops of the Qom Formation in the Naragh and Bijegan areas have been studied for a better understanding of environmental conditions of for- 
A
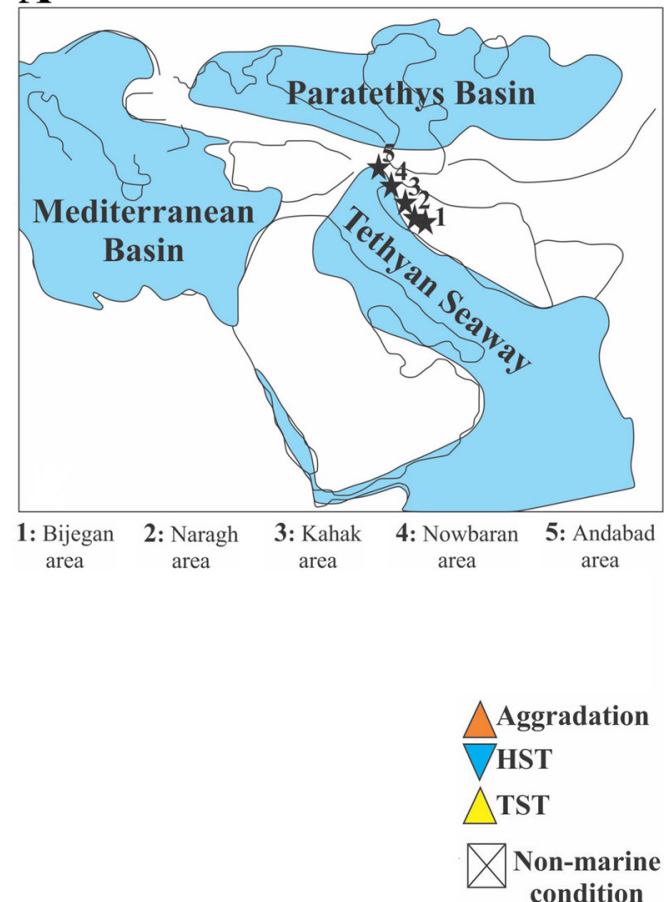

B

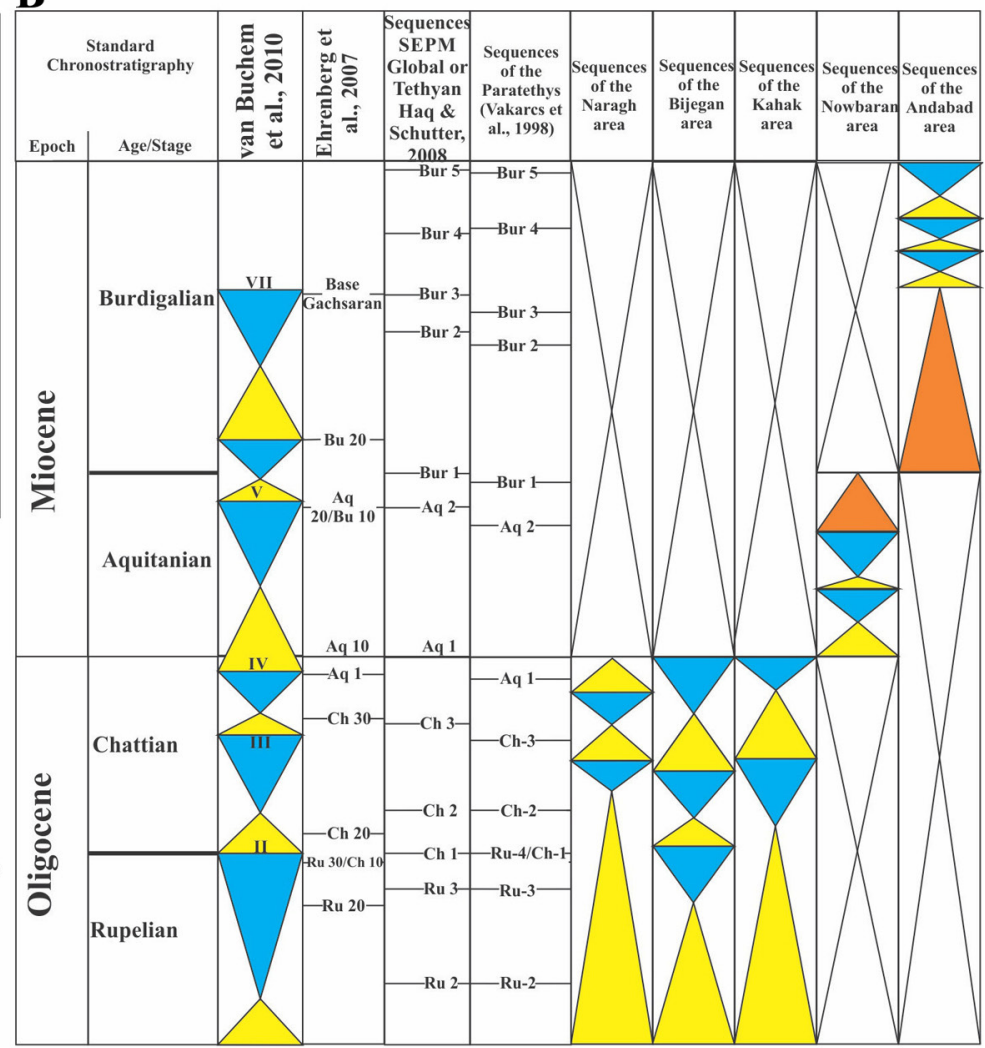

Fig. 14. A - Palaeogeographical map of the Tethyan seaway and Paratetethys basins during the Oligocene-Miocene (modified from Rögl, 1997). B - Correlation of sea level changes and depositional sequences between the study areas with the southern Tethyan seaway and the Paratethys basins

mation of these units in the Qom Basin (northern seaway basin). Our results show that:

1. microfacies recognised characterise a carbonate platform developed on an open shelf without effective barriers (reefal, oolitic and bioclastic barriers) separating it from the sea. They are grouped into two sedimentary environments representing a lagoon (restricted and semi-restricted) and an open-marine environment.

2. based on microfacies analysis, three third-order depositional sequences in the Bijegan area and two third-order depositional sequences and an incomplete depositional sequence in the Naragh area have been recognised.

3. during the Rupelian and Chattian, sea level changes at these two localities were affected by local fault activity and sea level change of the Qom Basin was less influenced by fluctuation of global sea level change and other basins (southern Tethyan seaway and Paratethys basins). In fact, the Paratethys and southern Tethyan seaway basins probably did not connect to the northern Tethyan seaway basin (Qom Basin) during the Rupelian and Chattian.

\section{Acknowledgements}

We wish to thank the University of Isfahan for financial support and are grateful to Dr Ryan Sincavage and Dr Paul Dunlop, who improved our earlier manuscript.

\section{References}

Abaie, I., Ansari, H.J., Badakhshan, A. \& Jaafari, A., 1964. History and development of the Alborz and Sarajeh fields of Central Iran. Bulletin of Iranian Petroleum Institute 15, 561-574.

Afzal, J., Williams, M., Leng, M. J. \& Aldridge, R.J., 2011. Dynamic response of the shallow marine benthic ecosystem to regional and pan-Tethyan environmental change at the Paleocene-Eocene boundary. Palaeogeography, Palaeoclimatology, Palaeoecology 309, 141160.

Aghanabati, A., 2006. Geology of Iran. Teheran: Geological Survey of Iran, 586 pp. (in Persian).

Allahkarampour Dill, M., Seyrafian, A. \& Vaziri-Moghaddam, H., 2010. The Asmari Formation, north of the Gachsaran (Dill anticline), southwest 
Iran: facies analysis, depositional environments and sequence stratigraphy. Carbonates Evaporites 25, 145160.

Allison, P.A. \& Bottjer, D.J., 2011. Taphonomy: process and bias through time. New York: Springer, $17 \mathrm{pp}$.

Amirshahkarami, M., Vaziri-Moghaddam, H. \& Taheri, A., 2007. Paleoenvironmental model and sequence stratigraphy of the Asmari Formation in southwest Iran. Historical Biology 19, 173-183.

Bassi, D., Hottinger, L. \& Nebelsick, J.H., 2007. Larger foraminifera from the Upper Oligocene of the Venetian area, North-East Italy. Paleontology 50, 845-868.

Basso, D., 1988. Deep rhodolith distribution in the Pontian Islands, Italy: a model for the paleoecology of a temperate sea. Palaeogeography, Palaeoclimatology, Palaeoecology 137, 173-187.

Beavington-Penney, S.J., 2004. Analysis of the effects of abrasion on the test of Palaeonummulites venosus: implications for the origin of nummulithoclastic sediments. Palaios 19, 143-155.

Beavington-Penney, S.J. \& Racey, A., 2004. Ecology of extant nummulitids and other large benthic foraminifera: applications in palaeoenvironmenanalysis. Earth-Science Reviews 67, 219-265.

Beavington-Penney, S.J., Wright, V.P. \& Racey, A., 2006. The middle Eocene Seeb Formation of Oman: an investigation of acyclicity, stratigraphic completeness, and accumulation rates in shallow marine carbonate settings. Journal of Sediment Research 76, 1137-1161.

Beavington-Penney, S.J., Wright, V.P. \& Woelkering, W.J., 2004. Recognising macrophytevegetated environments in the rock record: a new criterion using "hooked" forms of crustose coralline red algae. Sedimentary Geology 166, 1-9.

Beresi, M.S., Cabaleri, N.G., Löser, H. \& Armella, C., 2016. Coral patch reef system and associated facies from southwestern Gondwana: paleoenvironmental evolution of the Oxfordian shallow-marine carbonate platform at Portada Covunco, Neuquén Basin, Argentina. Facies 63, 1-22.

Bover-Arnal, T.E.L.M., Ferràndez-Cañadell, C.A.R.L.E.S., Aguirre, J., Esteban, M., Fernández-Carmona, J.O.S.É., Albert-Villanueva, E.D.U.A.R.D. \& Salas, R., 2017. Late Chattian platform carbonates with benthic foraminifera and coralline algae from the Seiberian plate. Palaios 32, 61-82.

Bozorgnia, F., 1966. Qom Formation Stratigraphy of the Central basin of Iran and its intercontinental position. Bulletin of the Iranian Petroleum Institute 24, 69-75.

Brandano, M., Cornacchia, I., Raffi, I. \& Tomassetti, L., 2016. The Oligocene-Miocene stratigraphic evolution of the Majella carbonate platform (Central Apennines, Italy). Sedimentary Geology 333, 1-14.

Brandano, M., Frezza, V., Tomassetti, L. \& Cuffaro, M., 2009. Heterozoan carbonates in oligotrophic tropical waters: the Attard member of the lower coralline limestone formation (Upper Oligocene, Malta). Palaeogeography, Palaeoclimatology, Palaeoecology 274, 54-63.

Brandano, M., Morsilli, M., Vannucci, G., Parente, M., Bosellini, F. \& Mateu-Vicens, G., 2010. Rhodolith-rich lithofacies of the Porto Badisco Calcarenites (upper
Chattian, Salento, southern Italy). Italian Journal of $\mathrm{Ge}$ oscience 129, 119-131.

Corda, L. \& Brandano, M., 2003. Aphotic zone carbonate production on a Miocene ramp, Central Apennines, Italy. Sedimentary Geology 161, 55-70.

Ćosović, V., Drobne, K. \& Ibrahimpašić, H., 2012. The role of taphonomic features in the palaeoecological interpretation of Eocene carbonates from the Adriatic carbonate platform (PgAdCP). Neues Jahrbuch für Geologie und Paläontologie 265, 101-112.

Daneshian, J. \& Ramezani Dana, L., 2007. Early Miocene benthic foraminifera and biostratigraphy of the Qom Formation, Deh Namak, Central Iran. Journal of Asian Earth Science 29, 844-858.

Dozy, J., 1944. Comments on geological report no. 1 by Thiebaud (on the Qom Saveh area). Geological Report 308.

Dunham, R.J., 1962. Classification of carbonate rocks according to depositional texture. [In:] Ham, W. E. (Ed.): Classification of carbonate rocks, A symposium. America: American Association Petroleum Geologist, 108-121.

Ehrenberg, S.N., Picard, N.A.H., Laursen, G.V., Monibi, S., Mossadegh, Z.K., Svana, T.A., Aqrawi, A.A.M., McArthur, J.M. \& Thirlwall, M.F., 2007. Strontium isotope stratigraphy of the Asmari Formation (Oligocene - Lower Miocene), SW Iran. Journal of Petroleum Geology 30, 107-128.

Embry, A.F. \& Klovan, J.E., 1972. Late Devonian reef tract on northeastern Banks Island, Northwest territories. Bulletin of Canadian Petroleum Geology 19, 730-781.

Esrafili-Dizaji, B. \& Rahimpour-Bonab, H., 2013. A review of Permo-Triassic reservoir rocks in the Zagros area, SW Iran: influence of the Qatar-Fars arch. Journal of Petroleum Geology 36, 257-279.

Flugel, E., 2010. Microfacies of carbonate rocks. Berlin: Springer, $976 \mathrm{pp}$.

Furrer, M.A. \& Soder, P.A., 1955. The Oligo-Miocene marine formation in the Qum region (Central Iran). Proceeding of the 4th World Petroleum Congress, Rome, 267-277.

Geel, H., 2000. Recognition of stratigraphic carbonat platform and slope deposits: empirical models based on microfasies analysis of paleogene deposits in southestern Spain. Palaeogeography, Palaeoclimatology, Palaeoecology 1550, 211-238.

Ghalamghash, A. \& Babakhani, R., 1996. Geological map 1: 100,000. The Geological Survey and Mineral Exploration of Iran, 1.

Halfar, J. \& Mutti, M., 2005. Global dominance of coralline red-algal facies: a response to Miocene oceanographic events. Geology 33, 481-484.

Haq, B.U. \& Shutter, S.R., 2008. Sequences (SEPM Global or Tethyan). TS Creator: Time Scale Creator [Internet]. 2005-2013. Geologic Time Scale Foundation. Available from: https:/ / timescalecreator.org/.

Harzhauser, M. \& Piller, W.E., 2007. Benchmark data of a changing sea palaeogeography, palaeobiogeography and events in the Central Paratethys during the Miocene. Palaeogeography, Palaeoclimatology, Palaeoecology, 253/1, 8-31. 
Hottinger, L., 1997. Shallow benthic foraminiferal assemblages as signals for depth of their deposition and their limitations. Bulletin de la Société Géologique de France 168, 491-505.

Kovacs, S. \& Arnaud-Vanneau, A.A., 2004. Upper Eocene paleobathymetry approach based on paleo ecological assemblages from the Plesca Valley 2. Outcrop, transylva Nia. Acta Paleontologica Romania 4, 191-202.

Lee, J.J., 1990. Fine structure of the rhodophycean Porphyridium purpureum in situ in Peneroplis pertusus (Forskal) and P. acicularis (Batsch) and in axenic culture. The Journal of Foraminiferal Research 20, 162-169.

Loffler, S.B. \& Nebelsick, J.H., 2001. Palaeoecological Aspects of the Lower Oligocene Paisslberg Formation based on Molluscs and Carbonates. [In:] W.E. Piller \& M.W. Rasser (Eds): Paleogene of the Eastern Alps. Österreichische Akademie der Wissenschaften, Schriftenreihe der Erdwissenschaftlichen Kommission, Wien, 14, 641-670.

Loftus, W., 1854. On the geology of the portions of the Torco-Persian frontier and of the districts adjoining. Journal Geology London 10, 464-469.

Mahyad, M., Safari, A., Vaziri-Moghaddam, H. \& Seyrafian, A., 2018. Reconstruction of sedimentary environment, and depositional sequences based on microfacies of the Qom Formation in the Kahak area (Southwest of Qom city). Iranian Journal of Petroleum Geology 8, 32-48 (in Persian).

Mahyad, M., Safari, A., Vaziri-Moghaddam, H. \& Seyrafian, A., 2019. Biofacies, taphofacies, and depositional environments in the north of Neotethys Seaway (Qom Formation, Miocene, Central Iran). Russian Geology and Geophysics 60, 1709-1727 (In press).

Mohammadi, E., Hasanzadeh-Dastgerdi, M., Safari, A. \& Vaziri-Moghaddam, H., 2018. Microfacies and depositional environments of the Qom Formation in Barzok area, SW Kashan, Iran. Carbonates and Evaporites $1,1-14$.

Mohammadi, E., Hasanzadeh-Dastgerdi, M., Ghaedi, M., Dehghan, R., Safari, A., Vaziri-Moghaddam, H., Baizidi, C., Vaziri, M.R. \& Sfidari, E., 2013. The Tethyan Seaway Iranian Plate Oligo-Miocene deposits (the Qom Formation): distribution of Rupelian (Early Oligocene) and evaporate deposits as evidences for timing and trending of opening and closure of the Tethyan Seaway. Carbonates and Evaporites 28, 321-345.

Mohammadi, E., Safari, A., Vaziri-Moghaddam, H., Vaziri, M.R. \& Ghaedi, M., 2011. Microfacies analysis and paleoenviornmental interpretation of the Qom Formation, South of the Kashan, Central Iran. Carbonates and Evaporites 26, 255-271.

Morley, C.K., Kongwung, B., Julapour, A.A., Abdolghafourian, M., Hajian, M., Waples, D., Warren, J., Otterdoom, H., Srisuriyon, K. \& Kazemi, H., 2009. Structural development of a major late Cenozoic basin and transpressional belt in central Iran: The Central Basin in the Qom-Saveh area. Geosphere 5, 325-362.

Mossadegh, Z.K., Haig, D.W., Allan, T., Adabi, M.H. \& Sadeghi, A., 2009. Salinity changes during late Oligocene to early Miocene Asmari Formation deposition,
Zagros Mountains. Iran. Palaeogeography, Palaeoclimatology, Palaeoecology 272, 17-36.

Murray, J. W., 2006. Ecology and applications of benthic foraminifera. Cambridge: Cambridge University Press, $426 \mathrm{pp}$.

Nebelsick, J.H., Bassi, D. \& Drobne, K., 2000. Microfacies analysis and palaeoenvironmental interpretation of Lower Oligocene, shallow-water carbonates (Gornji Grad Beds, Slovenia). Facies 43, 157-176.

Nebelsick, J.H., Bassi, D. \& Lempp, J., 2013. Tracking paleoenvironmental changes in coralline algal-dominated carbonates of the Lower Oligocene Calcareniti di Castelgomberto formation (Monti Berici, Italy). Facies 59, 133-148.

Nebelsick, J.H., Bassi, D. \& Rasser, M.W., 2011. Microtaphofacies: Exploring the Potential for Taphonomic Analysis in Carbonates. [In:] P.A. Allison, \& D.J. Bottjer, (Eds.): Taphonomy. Aims and Scope Topics in Geobiology Book Series. Dordrecht: Springer, 337-373.

Nebelsick, J.H., Stingl, V. \& Rasser, M., 2001. Autochthonous facies and allochthonous debris flows compared: Early Oligocene carbonate facies patterns of the Lower Inn Valley (Tyrol, Austria). Facies, 44, 1-31.

Nogole-Sadat, M.A., 1985. Les zones de decrochement et les virgation structurales en Iran. Consequences de region de Qom. Tehran: Geological Survey of Iran, 55 pp.

Pomar, L., 2001. Types of carbonate platforms: a genetic approach. Basin Research 13, 313-334.

Pomar, L., Baceta, J.I., Hallock, P., Mateu-Vicens, G. \& Basso, D., 2017. Reef building and carbonate production modes in the west-central Tethys during the Cenozoic. Marine and Petroleum Geology 83, 261-304.

Pomar, L., Esteban, M., Martinez, W., Espino, D., De Ott, V.C., Benkovics, L. \& Leyva, T.C. 2015. Oligocene-Miocene carbonates of the Perla Field, Offshore Venezuela: Depositional model and facies architecture. [In:] C. Bartolini, \& P. Mann, (Eds.): Petroleum geology and potential of the Colombian Caribbean margin, New York. AAPG Mermoir, 647-674.

Pomar, L., Mateu-Vicens, G., Morsilli, M. \& Brandano, M., 2014. Carbonate ramp evolution during the Late Oligocene (Chattian), Salento Peninsula, southern Italy. Palaeogeography, Palaeoclimatology, Palaeoecology 404, 109-132.

Renema, W., 2002. Larger foraminifera as marine environmental indicators. Scripta Geology 124, 1-260.

Renema, W., 2006. Large benthic foraminifera from the deep photic zone of a mixed siliciclastic-carbonate shelf of East Kalimantan: Indonesia. Marine Micropaleontology 58, 73-82.

Reuter, M., Pillar, W.E., Harzhauser, M., Mandic, O., Berning, B., Rogl, F., Kroh, A., Aubry, M.P., Wielandt, U. \& Hamedani, A., 2009. The Oligo-Miocene Qom Formation (Iran): evidence for and early Burdigalian restriction of Tethyan Seaway and closure of its Iranian getways. International Journal of Earth Sciences 98, 627-650.

Riegl, B., Poiriez, A., Janson, X. \& Bergman, K.L., 2010. The gulf: facies belts, physical, chemical, and biological parameters of sedimentation on a carbonate ramp. [In:] Westphal, H., Riegl, B. \& Eberli, G.P. (Eds): Car- 
bonate Depositional Systems. Assessing Dimensions and Controlling Parameters, New York: Springer, 145-213.

Rögl, F., 1997. Palaeogeographic considerations for Mediterranean and Paratethys seaways (Oligocene to Miocene). Annalen des Naturhistorischen Museums in Wien. Serie A 99, 279-310.

Rögl, F., 1999. Mediterranean and Paratethys. Facts and hypotheses of an Oligocene to Miocene paleogeography (short overview). Geologica Carpathica 50, 339-349.

Romero, J., Caus, E. \& Rossel, J., 2002. A Model for the Palaeoenvironmental distribution of larger foraminifera based on Late Middel Eocene deposits on the margine of the south Pyrenean Basine (SE Spain). Palaeogeography, Palaeoeclimatology, Palaeoecology 179, 43-56.

Sarkar, S., 2017. Microfacies analysis of larger benthic foraminifera-dominated Middle Eocene carbonates: a palaeoenvironmental case study from Meghalaya, NE India (Eastern Tethys). Arabian Journal of Geoscience 5, 1-13.

Schmidt, C., Heinz, P., Kucera, M. \& Uthicke, S., 2011. Temperature-induced stress leads to bleaching in larger benthic foraminifera hosting endosymbiotic diatoms. Limnology and Oceanography 56, 1587-1602.

Schmiedl, G., Scherbacher, M., Bruch, A.A., Jelen, B., Nebelsick, J.H., Hemleben, C., Mosbrugger, V. \& Rifelj, H., 2002. Paleoenvironmental evolution of the Paratethys in the Slovenian Basin during the Late Paleogene. International Journal of Earth Sciences, 91, 123-132.

Seddighi, M., Vaziri-Moghaddam, H., Taheri, A. \& Ghabeishavi, A., 2011. Depositional environment and constraining factors on the facies architecture of the
Qom Formation, Central Basin, Iran. Historical Biology 24, 91-10.

Silvestri, G., Bosellini, F.R. \& Nebelsick, J.H., 2011. Microtaphofacies analysis of lower Oligocene turbid-water coral assemblages. Palaios 26, 805-820.

Stocklin, J. \& Setudehnia, A., 1971. Stratigraphic Lexicon of Iran. Tehran: Geological Survey of Iran Publication, $376 \mathrm{pp}$.

Tomassetti, L., Benedetti, A. \& Brandano, M., 2016. Middle Eocene seagrass facies from Apennine carbonate platforms (Italy). Sedimentary Geology 335, 136-149.

Vakarcs, G., Hardenbol, J., Abreu, V.S., Vail, P.R., Várnai, P. \& Tari, G., 1998. Oligocene-Middle Miocene depositional sequences of the central Paratethys and their correlation with regional stages. SEPM Special Publication 60, 209-231.

van Buchem, F.S.P., Allan, T.L., Laursen, G.V., Lotfpour, M., Moallemi, A., Monibi, S., Motiei, H., Pickard, N.A.H., Tahmasbi, A.R., Vedrenne, V. \& Vincent, B., 2010. Regional stratigraphic architecture and reservoir types of the Oligo-Miocene deposits in the Dezful Embayment (Asmari and Pabdeh Formations), SW Iran. Geological Society, London, Special Publications 32/9, 219-263.

Wilson, M.E.J. \& Evans, M.E.J., 2002. Sedimentology and diagenesis of Tertiary carbonates on the Mangkalihat Penninsula, Boreneo: implications for subsurface reservoir quality. Marine and Petroleum Geology 19, 873900.

Manuscript received: 6 November 2018 Revision accepted: 15 July 2020 